SMALL BUSINESS ETHICS:

\title{
AN EXPLORATORY STUDY EXAMINING THE ETHICAL ISSUES OF CANADIAN WOMEN INVOLVED IN INTERNATIONAL TRADE
}

\author{
by \\ Rosangela Coscarella, \\ Bachelor of International Business
}

\begin{abstract}
A thesis submitted to
The Faculty of Graduate Studies and Research

in partial fulfillment of the requirements for the degree of

Master of Business Administration
\end{abstract}

Sprott School of Business

Carleton University

Ottawa, Canada

Ccopyright

R. Coscarella, 2005 


$\begin{array}{ll}\begin{array}{l}\text { Library and } \\ \text { Archives Canada }\end{array} & \begin{array}{l}\text { Bibliothèque et } \\ \text { Archives Canada }\end{array} \\ \begin{array}{l}\text { Published Heritage } \\ \text { Branch }\end{array} & \begin{array}{l}\text { Direction du } \\ \text { Patrimoine de l'édition }\end{array} \\ \begin{array}{l}\text { 395 Wellington Street } \\ \text { Ottawa ON K1A ON4 }\end{array} & \begin{array}{l}\text { 395, rue Wellington } \\ \text { Ottawa ON K1A ON4 } \\ \text { Canada }\end{array}\end{array}$

Your file Votre référence

ISBN: 0-494-13455-0

Ourfile Notre référence

ISBN: 0-494-13455-0

NOTICE:

The author has granted a nonexclusive license allowing Library and Archives Canada to reproduce, publish, archive, preserve, conserve, communicate to the public by telecommunication or on the Internet, loan, distribute and sell theses worldwide, for commercial or noncommercial purposes, in microform, paper, electronic and/or any other formats.

The author retains copyright ownership and moral rights in this thesis. Neither the thesis nor substantial extracts from it may be printed or otherwise reproduced without the author's permission.
AVIS:

L'auteur a accordé une licence non exclusive permettant à la Bibliothèque et Archives Canada de reproduire, publier, archiver, sauvegarder, conserver, transmettre au public par télécommunication ou par l'Internet, prêter, distribuer et vendre des thèses partout dans le monde, à des fins commerciales ou autres, sur support microforme, papier, électronique et/ou autres formats.

L'auteur conserve la propriété du droit d'auteur et des droits moraux qui protège cette thèse. $\mathrm{Ni}$ la thèse ni des extraits substantiels de celle-ci ne doivent être imprimés ou autrement reproduits sans son autorisation.
In compliance with the Canadian

Privacy Act some supporting forms may have been removed from this thesis.

While these forms may be included in the document page count, their removal does not represent any loss of content from the thesis.
Conformément à la loi canadienne sur la protection de la vie privée, quelques formulaires secondaires ont été enlevés de cette thèse.

Bien que ces formulaires aient inclus dans la pagination, il n'y aura aucun contenu manquant.

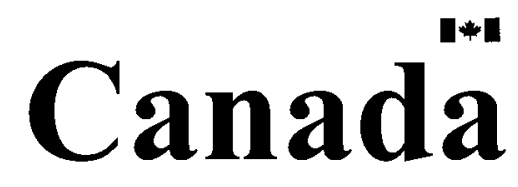




\begin{abstract}
This thesis examines business ethics within the context of small businesses, specifically it observes the ethical issues encountered by Canadian exporting women entrepreneurs and it outlines the actions they take to resolve these challenges. A sample of 54 Canadian women small business owners was used to identify the most prevalent ethical issues and resolution strategies employed.
\end{abstract}

Findings from this research show that these small business owners experienced issues in 11 categories; including gender and equity, bureaucracy, dishonesty and banking issues. In addition, evidence of the use of managerial strategies (organizational integrity and legal compliance) was found. This study also reinforces that small businesses often do not have structured or institutionalized codes in place to deal with ethical issues. The results of this study will be useful to researchers and especially to small business owners seeking to implement measures that may assist in recognizing and dealing with ethical challenges. 


\section{Acknowledgements}

There are several individuals that deserve to be thanked for helping me along this journey. To my supervisors, Dr. Judith Madil1, Dr. Barbara Orser and Dr. Allan Riding. Thank you for your constant support, encouragement and expertise. I have learned so much throughout this process and it has been a pleasure working with each of you. Thank you to the Committee Chair Dr. George Haines and the external examiner Dr. Karen March for your constructive comments and suggestions.

To my Mamma, Papa and Antony, thank you for always encouraging me in my decisions and for the opportunities to grow and succeed. I could not have done it without you all. 


\section{Table of Contents}

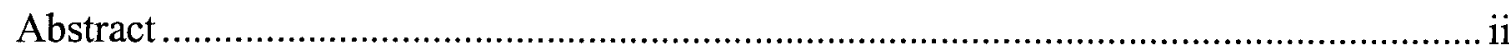

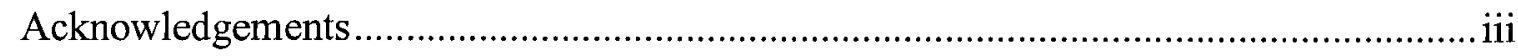

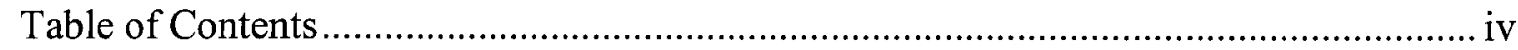

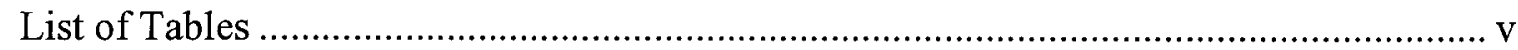

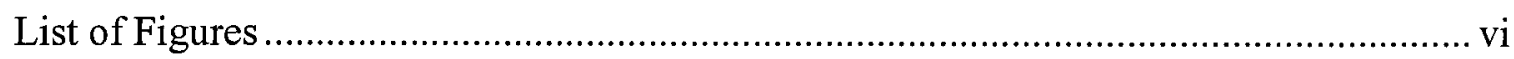

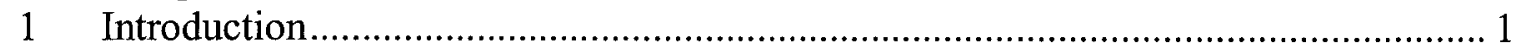

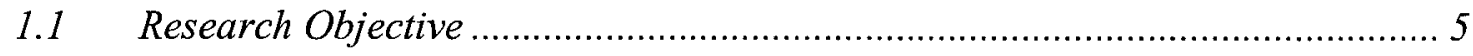

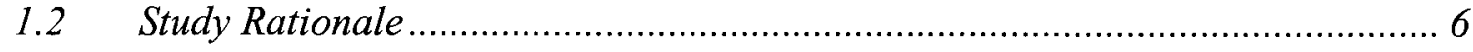

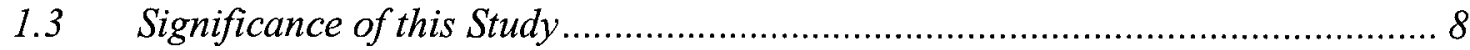

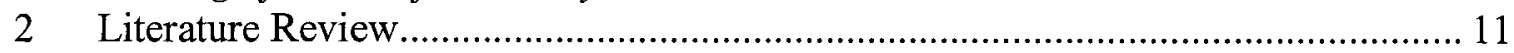

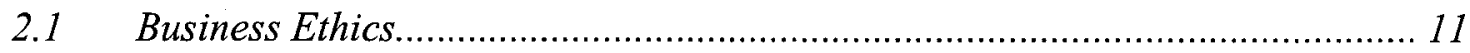

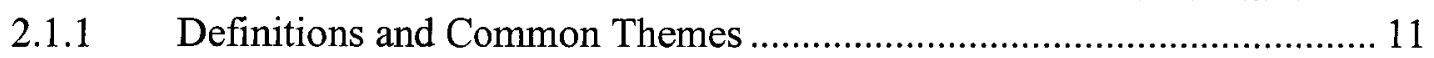

2.1.2 The Importance of Business Ethics...................................................... 13

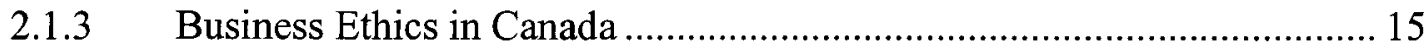

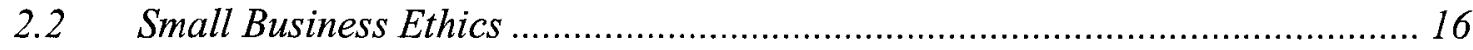

2.2.1 Key Research Findings ..................................................................... 16

2.2.2 Ethical Dilemmas and Resolution Framework ................................... 27

2.2.3 Managerial Strategies Used to Direct Ethical Issues ............................... 31

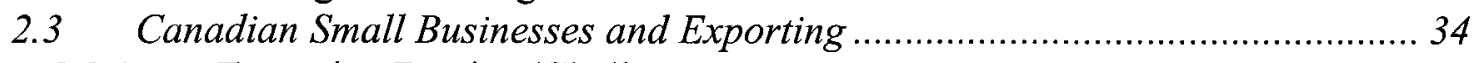

2.3.1 Exporting Barriers/Challenges......................................................... 34

2.3.2 Women Entrepreneurs and Exporting............................................... 36

$2.4 \quad$ Critique of the Literature ................................................................................ 38

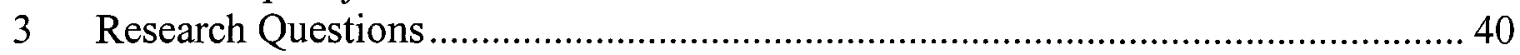

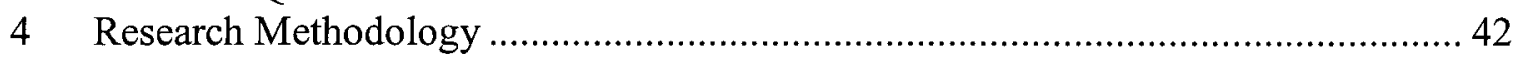

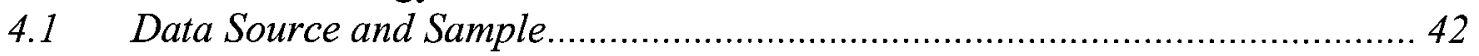

4.2 Research Instrument ............................................................................ 45

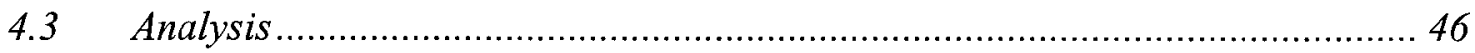

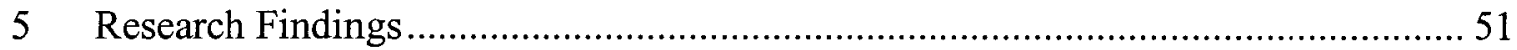

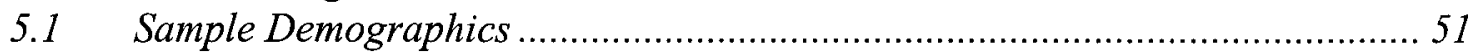

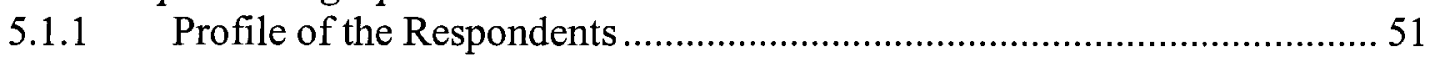

5.1.2 Profile of the Small Businesses.............................................................. 53

$5.2 \quad$ Results Associated With Research Questions 1 \& 2 .................................. 55

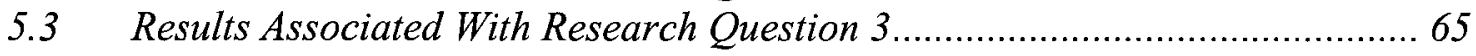

5.4 Results Associated With Research Question 4..............................................6 66

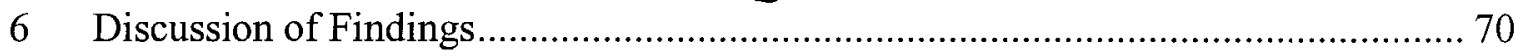

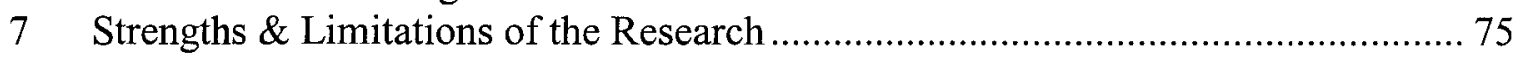

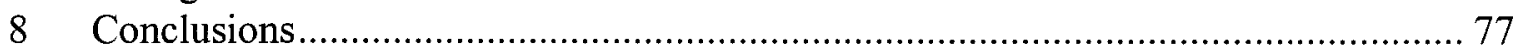

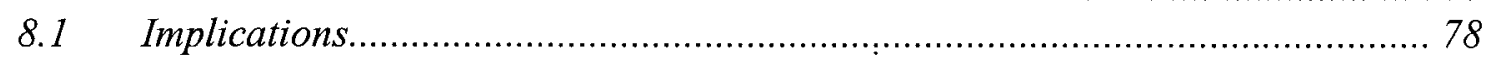

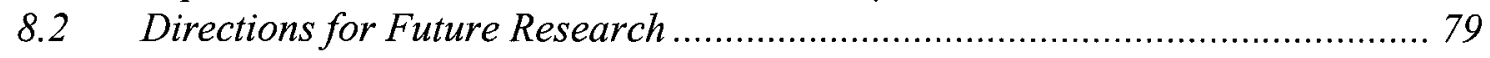

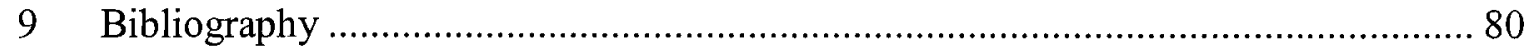

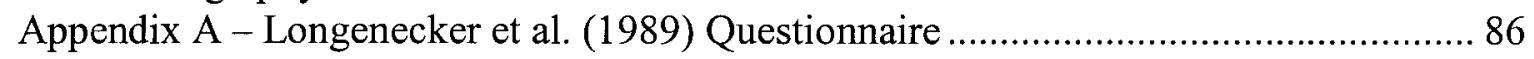

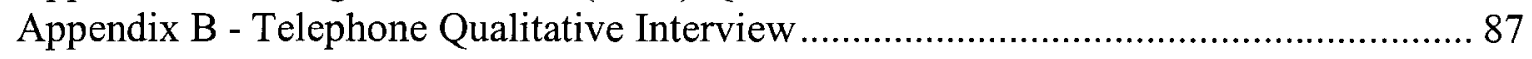

Small Business Ethics in Canada iv

R. Coscarella 


\section{List of Tables}

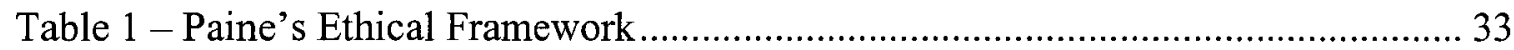

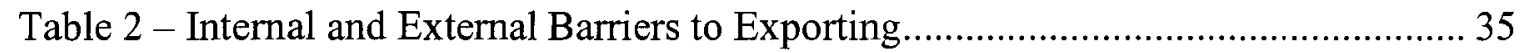

Table 3 - Analysis of Ethics in the Literature ........................................................... 46

Table 4 - Ethical Problem Categories in International Marketing ............................... 48

Table 5 - Geographic Representation of the Participants............................................. 51

Table 6 - Active Exporters and Export Planners Business Experience........................... 53

Table 7 - Sectoral Distribution of Respondent Firms ................................................. 54

Table 8 - Explanation of Ethical Issues................................................................... 57

Table 9 - Ethical Issues for Women Small Business Owners Who are Export Planners 61

Table 10 - Ethical Issues for Women Small Business Owners Who are Active.............. 61

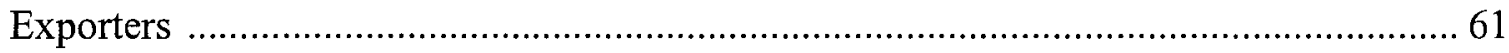

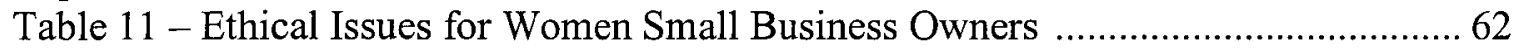

Table 12 - Evidence of Managerial Strategies demonstrated by Respondents ............... 67 


\section{List of Figures}

Figure 1 - Evolution in the ethical reference point as ventures grow ........................... 27

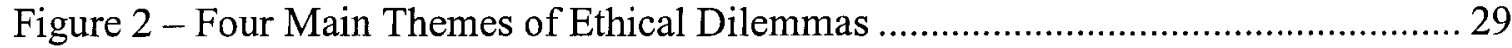

Figure 3 - Web filters used to resolve ethical dilemmas ........................................ 30 


\section{Introduction}

The objectives of this thesis are to explore ethics within the context of small businesses, specifically to observe the ethical issues encountered by Canadian exporting entrepreneurs and to outline the actions they take to resolve these challenges. In an attempt to further centre the study, all the small businesses observed in this thesis are owned by women.

Nobel Prize winning economist Milton Friedman argues that the sole social responsibility of a business is to increase its profits (Poff, 2005; Joyner Payne and Raiborn, 2002). Friedman also states that a business is an artificial legal entity, with its only fiduciary responsibility being to the shareholders. Businesses, he claims, must “...use its resources and engage in activities designed to increase its profits so long as it stays within the rules of the game...engaging in open and free competition without deception or fraud" (Friedman, 1970; p.6).

On the other hand, in a recent address, Chairman and CEO of Four Seasons Hotels and Resorts Isadore Sharp, stated that business ethics is no longer "...considered to be a matter of personal conscience" and that companies are putting ethics at the forefront of everyone's mind as "...the value of an ethical reputation is rapidly rising." 1 Other researchers and ethicists argue that Friedman's perspective of conducting business is inappropriate and limited, and they would agree with Sharp's perspective of the role

\footnotetext{
${ }^{1}$ Taken from the Notes for an Address by Isadore Sharp to the Administrative Sciences Association of Canada Conference hosted by Ryerson University on May 30, 2005. 
ethics play in today's business world. Ethics play a fundamental role in the daily business activities of organizations of all sizes and are the major part of the organizational culture of a business (Huberman-Arnold and Arnold, 2003; Paine, 1994). An organization's contribution to society is as important as the revenues it generates (Stodder, 1998). During the past decade, both large and small businesses have been the topic of much public scrutiny, in part due to the effects of globalization, advancements in technology, competition and public perception of the law (Paine, 1996). The Enron scandal, for example, is known around the world for its devastating corporate collapse and proves that an organization cannot simply print an ethics code, post it on the wall and pray for good things to happen. The ethical culture of an organization needs to be supported and maintained in order for the ethical vision to come true. These scandals are by no means limited to private sector firms, as the sponsorship program of the Canadian Liberal government demonstrated. As a result, organizations of all types need to consider ethics as part of everyday operations and not ignore it.

Within the context of small business, ethics has received very little attention by the research community, in part due to the difficulty of gathering the necessary data from small businesses (Quinn, 1997; Ryan, 1991). The literature on small business ethics and the entrepreneur is in its infancy and therefore many areas remain to be explored and validated. As there are many more small businesses than large businesses within the Canadian economy, the relevance of research in this area could prove especially beneficial to all small business owners and practitioners. 
The findings from the research conducted thus far on corporate business ethics have been often applied to the area of small business ethics, assuming that the two business environments are the same (Spence, 1999). However, it has also been determined by the research community that small businesses vary in comparison to their large business counterparts (Brown and King, 1982; Chrisman and Fry, 1982; Wilson, 1980) and that ethical issues and ethical resolution approaches differ among small businesses (Vyakarnam, Bailey, Burnett and Myers, 1997). To date, it is known that entrepreneurs and corporate managers demonstrate varying perceptions when encountered with the same ethical situation (Hornsby, Kuratko, Naffziger, LaFollette and Hodgetts, 1994; Longenecker, McKinney and Moore, 1989). It has also been found that entrepreneurs are motivated by more than just the law by demonstrating acts of social responsibility (Joyner et al., 2002). In addition, the research shows that entrepreneurs' personal ethics influence business decision-making (Dawson, Breen and Satyen, 2002; Hornsby et al., 1998; Quinn, 1997), although this last point has often been debated as to whether religious beliefs have any bearing on business issue resolution approaches (Spence and Lozano, 2000).

The literature, however has yet to incorporate the nexus between exporting and the ethical environment of small firms. This is the first Canadian study, which the author can identify, to explore ethics in small businesses. In addition, it is the first national study to examine the ethical barriers associated with international trade. As global business activities continue to expand, and not only for large corporations, this is a logical step in advancing the research on small business ethics. 
In general terms, ethics involves learning what is right or wrong and then doing the right thing. Business ethics is an extension of this definition and involves knowing what is right or wrong in the workplace and doing what is right (Hornsby et al., 1994; Donaldson and Werhane, 1993). Subsequent definitions will be examined in the following chapters. Many definitions also exist for the term entrepreneur, ranging from academic sources to practitioner articles. This thesis does not attempt to be exhaustive in defining this term, but rather chooses a common definition that will serve the purposes of the research. Therefore, an entrepreneur is defined as “... an individual who establishes and manages a small sized business for the principal purposes of profit and growth" (Carland, Hoy, Boulton and Carland, 1984; p.358). As a result, the terms entrepreneur and small business owner are used interchangeably. The definition of a small business has also varied greatly (Curran and Blackburn, 1994), as different institutions define a small business in terms that are suitable for them. Adopting the definition used in previous research, a small business is "... actively managed by the owner(s); highly personalized; largely local in its area of operation; and largely dependent on the internal sources of capital to finance growth" (Vyakarnam et al., 1997; p.1630). This definition accentuates the key differences between small and large businesses, including the notion that the same person owns and manages the small firm. For the purposes of this thesis, a small business is defined as a firm employing less than 100 people (Industry Canada as quoted by Business Register of Statistics Canada, 2005) and records annual export sales under $\$ 1$ million (Export Development Canada as quoted by Business Register of Statistics Canada, 2005). 
This thesis is divided into eight chapters. The first chapter presents the research objectives, study rationale and the significance of this study. The literature relevant to this research is presented in chapter two. The literature review is divided into four sections: business ethics, small business ethics, Canadian small business exporting and a critique of the literature. The third chapter outlines the research questions, followed by chapter four, which discusses the methodology implemented in this study. Chapter five presents the respondent demographics and findings, followed by chapter six which outlines the discussion of the findings. In the final chapters, the strengths and limitations of the research are outlined in chapter seven, while the conclusions and directions for future research are summarized in chapter eight.

\subsection{Research Objective}

The objective of this thesis is to document the ethical issues facing small Canadian exporting businesses owned by women. There is no Canadian research to date on the ethical problems that directly face small firms that engage in international trade. It is also unclear what factors influence ethical decision-making in the small firm context when exporting. Examining how women small business owners/entrepreneurs respond to the ethical dilemmas may provide insights into how ethical issues are dealt with in medium and large firms participating in international trade and it will provide the groundwork for future studies. Therefore, an effort will be made to:

- Primarily, identify any ethical issues encountered by women-owned Canadian exporting small businesses;

- Followed by an attempt to classify issues into frameworks available in the literature; 
- Examine if any resolution strategies are employed by entrepreneurs;

- Document any managerial strategies used to mitigate ethical issues.

\subsection{Study Rationale}

Huberman-Arnold and Arnold (2003) present four reasons why organizations should act in an ethical fashion. (1) Sustainability suggests that unethical businesses are not able to survive. (2) Obtaining sustained profitability by "doing well by doing good". (3) Due to a higher level of ethical standards, good people are better managers. (4) Employees want to work in an environment that encourages good behaviour and leads to beneficial outcomes. Preliminary findings show that large businesses that have engaged in consistent ethical behaviour have not been harmed or placed at a disadvantage. Unethical behaviour, on the other hand, has in fact negatively affected business operations (Huberman-Arnold and Arnold, 2003). In addition, it has been suggested that integrity and good ethical behaviour in small businesses can contribute to its competitive advantage (Small Business Research Centre, 1997; Wilson, 1980) because it allows a company to distinguish itself from its competitors within the general business environment (Vyakarnam et al., 1997).

Joyner et al. (2002), Quinn (1997), Ryan (1991), Thompson and Smith (1991) all note that the majority of the research conducted on business ethics concentrates on large businesses. This is mainly due to an increased facilitation to gather data from large businesses, the importance the media and society place on large organizations, how large firms affect a larger number of people simultaneously and that research methodologies used in studies for large corporations are not adaptable to the small business setting

R. Coscarella 
(Thompson and Smith, 1991). The tendency might be to conclude that the results drawn from the studies on large business ethics apply to the small firm setting as well. However, there are several justifications for separating ethical studies for large and small businesses. Because each have different processes, functions and ways of approaching business, comparing ethical attitudes and behaviours is rendered more difficult (Spence, 1999; Hornsby et al., 1994; Humphreys et al., 1993). For example, Longenecker and Schoen (1975) found that entrepreneurs applied different approaches to business in terms of “...innovation, risk-taking and independent action." Spence (1999) also outlined six additional characteristics distinctive to the small business; independent, owner-managed, multi-tasking, cash-limited (firefighting), personal relationships and informal controls (Spence, 1999). For instance, the control within a small firm is in the hands of the entrepreneur (owner), thus allowing them to make the business decisions. In addition, the entrepreneur must manage many tasks simultaneously, while dealing with the constraints of limited cash. Owners of small firms must often concentrate on daily short-term survival issues rather than long-term goals. The lack of bureaucratic controls often associated with small firms facilitates openness and trust in building more personal relationships with employees, customers and suppliers. Each element listed above is unique from large businesses thus demonstrating that small firms do not just differ in size from large firms, but in nature as well. Therefore, it can be implied that the ethical issues that arise are different from those than in the large firms (Vyakarnam et al., 1997). Small business ethics requires a separate analysis and cannot be combined with business ethics as it pertains to large businesses. 


\title{
1.3 Significance of this Study
}

In her research, Spence examines the literature on small business ethics stating that "...if business ethics is to come of age, the inclusion of a small firm perspective in its remit is essential." She continues by saying that,

\begin{abstract}
“The possibility for impacting individual lives, organizational effectiveness and policy practicality through our investigations are significant. In Europe which is desperately concerned with employment opportunities, work quality, social inclusion, environmental management and competitiveness, the time is particularly ripe for small business ethics." (Spence, 1999; p. 163)
\end{abstract}

Why is it important to study business ethics within the context of small businesses? Small businesses are an important element in almost every economy around the globe. In Canada, a small business is defined as a firm employing less than 100 people and makes up 97 percent of all Canadian organizations, employing 56 percent of the Canadian working population (Business Register of Statistics Canada, 2005). Small businesses greatly contribute to society through employment and social contributions, but research priority has been given mainly to the state of large businesses. Given the impact that small businesses have on the state of the economy, "...the attention of commentators on business ethics to small business is not only an oversight, but also a mistake, (especially if researchers) wish to make their work of relevance to business owners and practitioners" (Spence, 1999; p.163). Quinn (1997), Masters and Solymossy (2000) present another important reason for researching small business ethics. They claim that large businesses are becoming less hierarchical and more entrepreneurial in nature. It is suggested that ethics in large organizations can be enhanced by having a greater 
understanding of the influences ethics has on small firms and their entrepreneurs (Masters and Solymossy, 2000; Quinn, 1997).

Why is it important to study the ethical issues encountered by women entrepreneurs who engage in exporting? Exporting is often used as a form of growth for small businesses, thus making it an important area for entrepreneurs and small business owners to be more informed of. As these businesses continue to grow, more and more jobs become available for Canadian residents. In today's more global business environment, the tendency for entrepreneurs to be confronted by ethical issues in the international environment is becoming more and more of a reality. According to Mayo (1990), ethical problems “... appear to be a potent 'perceived barrier' in that many (US marketers) report they tend to avoid foreign markets where they expect to encounter ethical dilemmas" (Mayo, 1990; p.51). This perceived barrier might have a strong negative impact on foreign trade objectives for small businesses. Therefore, it is essential to be more knowledgeable of the issues that could arise and to be equipped with the correct coping tools.

Women entrepreneurs are continuously growing in number and represent 45 percent $^{2}$ of all Canadian business owners (Industry Canada, 2002). McRea (1999) notes that “...few studies are done specifically on the characteristics of women-owned business in export...and studies on export decision-making or behaviour do not use gender as a variable" (McRea, 1999; p.2). By concentrating solely on women business owners, it gives this study a more focused approach and creates a basis for future studies. 
This research will be significant to the small business ethics literature, as well as the literature on women exporting entrepreneurs. By determining what challenges women entrepreneurs are encountered with, it will create the foundation to answer additional research questions, including if significant differences exist among male and female entrepreneurs. As more businesses continue to use exporting as a means of growth, an increased understanding of the ethical implications and resolution strategies employed by entrepreneurs will also provide a basis for better understanding of medium and large businesses engaging in international trade. In addition, women ownership of businesses is increasing in Canada and it is important to understand what ethical issues can potentially impede or facilitate international activities. As this is the first exploratory study to tackle this research area, it will be significant in establishing direction for future research.

\footnotetext{
${ }^{2}$ The 45 percent (647 000 Canadian firms) represent women that had a least some degree of female ownership in 2002. Of those, some 211000 firms were majority owned by women, while 272000 were owned by equal partnership between male and female owners.
} 


\section{Literature Review}

This literature review is divided into four main sections. The first section examines the field of business ethics and provides a brief look at business ethics within the Canadian context. The next section concentrates on the current research available within the area of small business ethics and how it has developed over the past two decades. Section three provides a general overview of Canadian small business exporters. The final section will present a critique of the existing literature.

\subsection{Business Ethics}

Corporate ethics literature is reasonably developed as researchers have been interested in this area for more than forty years. The field was formally recognized as a specific discipline that interested researchers in the 1960s (McMahon, 1999). The following three sections will focus on the area of business ethics as a whole, presenting varying definitions of business ethics, a brief summary of the common themes within research findings, an explanation of the importance of the topic and a brief synopsis of business ethics research in Canada.

\subsubsection{Definitions and Common Themes}

There exist volumes of literature devoted in general terms to the matter of defining ethics. In an attempt to be non-exhaustive of the topic, the following examines a few common definitions used in numerous studies. According to Brown and King, “...ethics are rules for human behaviour, rules which take the form of 'oughts' and 'ought nots'. Ethics are used as guidelines for making decisions about how to act in specific situations and are also used to evaluate the actions of others." (Brown and King, 1982; p.1) Donaldson and 
Werhane (1993) defined ethics as "the study of whatever is right and good for humans" (Donaldson and Werhane, 1993 as sited in Hornsby et al., 1994; p. 9). Ethics involves judgments as to good and bad, right and wrong. They can be distinguished from 'morals' (rules or duties that govern behaviour as persons to persons) and from 'values' (which are ends or goals sought by individuals). An ethical dilemma exists when two or more values are in conflict and one seeks from ethics a resolution to this conflict (Hartman, 2002; p.2). Ethics is the way morals are applied to decisions. For the purposes of this discussion, ethics can be summarized as learning what is right or wrong and then doing the right thing.

Business ethics is an extension of the above definitions and involves knowing what is right or wrong in the workplace and to do what is right (Donaldson and Werhane, 1993) and preventing that the actions of one group put another group at a disadvantage. It has also been identified as the study that “...investigates business practices in light of human value" (Hornsby et al., 1994). Therefore, it has been debated whether or not business people take with them their human values when making purely business decisions, thus explaining the struggle in concretely defining such terms. Academics have also used business ethics to define other concepts, such as corporate social responsibility and conduct (Wood, 1991; Carroll, 1991) as these terms have frequently been assigned to the field of business ethics. However, the resistance to commit to one common definition continues to exist in the literature. 
In briefly reviewing the literature on corporate business ethics over the past couple of decades, there are some common themes that continuously re-surface. A complete recap of the research conducted in the area of business ethics over the past four decades will not be provided. Instead, a summary of the key points is offered. The first point that is consistent throughout the business ethics literature is that there is a call for businesses to acknowledge their social responsibility and ethical conduct (Werner, 1992; Evans, 1991; Andrews, 1989; Hector, 1989, Von der Embse and Wagley, 1988; Goddard, 1988; Berenbeim, 1987). That is, businesses must look beyond profits and realize the need to also act responsibly. Secondly, more and more businesses use corporate codes of ethics as a method of maintaining ethical procedures within the organization (Robin, Giallourakis, David and Mortiz, 1989; Brooks, 1989; McDonald and Zepp, 1989; Epstein, 1987). The third point pertinent throughout the business ethics literature is the examination of business executives' values and attitudes and using them as the ultimate basis for business systems (Enz, Dollinger and Daily, 1990; Kirrane, 1990; Cadbury, 1987). Lastly, it has been agreed to by researchers that the business ethics research emphasis on small business and the perceptions of its owners/entrepreneurs has not been given sufficient attention. Section two of this literature review will elaborate on this last point, thus demonstrating the importance of this topic, as it continues to reappear throughout the literature on business ethics as an area that requires consideration.

\subsubsection{The Importance of Business Ethics}

Business ethics are particularly interesting because they directly and strongly affect the society (including the environment) in which business operates, and not only within the internal business atmosphere. It is important to do what is right and not solely within the 
legal boundaries of proper conduct. Small business ethics specifically have not received the consideration of many researchers, but as the significance of small businesses increases in society, so do the importance of ethics and the development of strong corporate value systems in the small business context. Given the nature of this area, not many enlightening conclusions have surfaced. There is a fairly high level of consistency and a relatively low level of contradiction in arguments emerging from researchers and this could be attributed to the simple fact that there is not enough information to debate. What is available, however, may also have its flaws. Therefore, it is evident that this area requires fresh research findings.

Prior to and during the 1990 s and continuing into the new millennium, North America experienced what could be defined as an ethical crisis in business (Grier, 1991). It appeared as though everyday a new story of unethical behaviour by a business could be read in the newspaper. As large organizations are continuously under public scrutiny, society is much more aware of what takes place within these organizations. For example, when Nike and Kathy Lee Gifford were accused of engaging in child labour in sweatshops overseas, many consumers worldwide refrained from purchasing their merchandise. This situation continues to affect Nike's market position as many consumers wonder if such activity is occurring. Other popular examples, such as Maxwell's raiding of pension funds in the United Kingdom and the Exxon Valdez oil spill, show the repeated focus on the misdoings of large organizations (Quinn, 1997). Businesses, both small and large, have had to react to this changing environment, where ethics continues to play a larger role. For instance, changes have been made to 
employment policies, relationships with customers and suppliers, health and safety, and environment policies (Quinn, 1997). Although small businesses are less easily watched by the public (because the media does not always report such misdoings), the implications of good ethical behaviour appear to be very positive in nature.

\subsubsection{Business Ethics in Canada}

As Canadians may be motivated differently than citizens of other countries, the learning applications and experiences from the business ethics research may be unique (Brooks, 1997). Unlike the United States, Canada does not have governing regulatory bodies such as a Foreign Corrupt Practices Act or the Securities and Exchange Commission. Canadian business ethics have, therefore, developed by socio-political pressures, stakeholder demands and globalization (Brooks, 1997). Specifically, Canadians have shown a profound interest in the principles implemented throughout the accounting profession and this interest has encouraged greater awareness of ethical problems within Canadian businesses.

Researchers, however, have not yet shown an interest in exploring ethics within the context of small businesses. To date, the researcher could not identify any studies of small business ethics within the Canadian environment. Although many American research findings could potentially be applied to the Canadian context, it is important to have a body of research that portrays a truer image of small business ethics in Canada. Therefore, it is an added goal of this study to ignite interest in the subject and to encourage more researchers to examine the importance of this topic. 


\subsection{Small Business Ethics}

This next section will concentrate solely on the small business ethics literature. Researchers in the United States initiated research in this field in the 1980's and a large, extensive and well-developed literature has yet to exist on small business ethics. In reality, there is an obvious lack of appropriate research in this field (Spence, 1999). The North American research community has shown a greater interest in the accounting and environmental mishaps of the corporate world, for example the Enron and WorldCom financial scandals. Canadian researchers have not engaged in any studies pertaining to this area, as what little material is available has originated in the United States and Europe. To follow is a summary of the key research findings, the ethical dilemmas and resolution framework.

\subsubsection{Key Research Findings}

This section will examine the research conducted thus far, mainly following a chronological order by year. As very few studies overlap in terms of research findings, each study and its conclusions are important in building a fuller and more solidified literature.

Prior to 1989 , the research indicated that differences did in fact exist in the way that small businesses thought and behaved in comparison to other groups (Brown and King, 1982; Chrisman and Fry, 1982; Wilson, 1980), but not much was said about what types of differences were at hand. However, it was concluded that smaller firms better understood the implications of corporate social responsibility. According to the Brown and King (1982) study, small business owners thought that “...businesses have the chief 
responsibility for bringing ethical standards into business decision making" (Brown and King, 1982; p.17) and not society, as the mangers of large businesses concluded.

The next significant contribution in American literature came some years later. The 1989 study conducted by Longenecker, McKinney and Moore attempted to answer a very specific question; "Do small businesses have better ethics?" Although a hand full of methods have been used since, the survey instrument used in the Longenecker et al. (1989) study became the basis for several subsequent ethical research studies on small businesses for several years. Hornsby et al. (1994) and Smith and Oakley (1994) both used this exact instrument in their study, while Humphreys, Robin, Reidenbach and Moak (1993) used a scenario-based questionnaire developed by the Longenecker et al. (1989) study as inspiration. Therefore, it appears necessary and beneficial to briefly explain specific details of this study, as it became a reference point for many future studies.

Longenecker, McKinney and Moore compared the ethical views of 572 small business respondents and 785 large business respondents using sixteen business scenarios (Appendix A). The participants were asked to judge each by selecting one point on a seven-point Likert scale. The survey showed that small businesses differed in comparison to large firms on twelve of the sixteen scenarios. "On six of the twelve (differing) issues small firm respondents expressed more stringent ethical views...yet on six other issues, small firm respondents indicated a significantly more permissive stance" (Longenecker et al., 1989). Small business owners/entrepreneurs expressed more 
stringent ethical views on; faulty investment advice, promotion in favouritism, design flaw, misleading financial reporting, misleading advertising and defending healthfulness of cigarette smoking. On the other hand, it was shown that small businesses were more permissive on the following in comparison to large businesses; padded expense accounts, tax evasion, collusion in bidding, insider trading, discrimination against women and copying computer software. The Longenecker et al. research pioneered the use of scenario-based questionnaires within this area of research and it was considered quite useful in examining the differences of small business ethics. Longenecker et al. (1989) argue that no clear pattern of interpretation exists that aids in the explanation of the above differences. Yet the initial rationalization stemmed from the financial welfare of small businesses (Longenecker et al. 1989). Due to lack of financial resources often associated with small businesses, the respondents were more accepting of behaviours that involved saving money; for instance copying computer software instead of purchasing it directly from the manufacturer. In addition, these results may also be linked back to the fact that few small businesses advertise, engage in original product design and $\mathrm{R} \& \mathrm{D}$, thus attributing to the differences in attitudes.

Nevertheless, several limitations can be identified with this study. Firstly, the respondents were aware that they were being asked questions that pertained to ethical issues, which may have resulted in less than honest responses. Secondly, the majority of the vignettes outlined in the survey reflected illegal situations, as opposed to purely ethical ones. In addition, the study failed to determine if in fact small businesses had higher ethics. It did however reaffirm that indeed small business owners have differing 
perspectives than their large business manager counterparts when confronted with ethical and socially responsible issues.

Following the 1989 milestone study, the area of small business ethics advanced with a sequence of researchers adding specific elements of ethics research. In 1991, Mayo examined the ethical problems encountered by American small businesses, specifically within the area of international marketing. It was the first study to add the element of internationalization to the field of small business ethics. A sample of 192 small business participants from the District Export Council and the US Department of Commerce responded to the questionnaire. They were asked to identify aspects of international marketing that posed the most difficult ethical problems and to rate the frequency with which they occur, as well as indicate its impact on the firm and its management team. Five issues posed the most difficulty for small businesses engaged in international marketing; bribery, political issues/government interference, customs clearance, transfer of funds and cultural/business differences. Mayo (1991) also noted, “...management's inability to reliably identify business problems with moral implications may be another impediment to coping with ethical problems... and that the field of business ethics has not developed a precise vocabulary to assist managers in identifying, discussing and resolving ethical dilemmas" (Mayo, 1991; p.57).

Humphreys et al. (1993) tried to empirically analyze and compare the decision making process of entrepreneurs/small business owners and their customers, thus adding a new understanding of how small businesses behave and what is expected by the customer. The 
tool used to gather data was also scenario-based. It offered the respondents a situation and a description of a specific behaviour, where they were asked to identify the action as ethical or unethical in nature. The results showed that small businesses and their customers shared similar attitudes regarding unethical acts. For example, both small business respondents and customers considered product cheating to be an unethical act. The findings also showed that fairness and justice were used by small business owners and customers when determining if an action was ethical (Humphreys et al., 1993). However, no follow-up studies have been identified since to support or disprove the results extracted from this particular study.

Hornsby, Kuratko, Naffziger, LaFollette and Hodgetts (1994) made use of the Longenecker et al. (1989) study by performing a factor analysis on the scenarios. The purpose was to take the original study one step further by researching “...the possible existence of underlying dimensions which guide owner/managers' behaviour" (Hornsby et al., 1994; p.9-10) and to prove the utility of the scenario-based questionnaire to measure the ethical perceptions of small entrepreneurs. The findings were consistent with those of the original research, both were unable to determine if one group had better ethics. The scenarios from the questionnaire were grouped into four principal factors; Business Development/Profit Motive, Money-Related Theft, Administrative Decision Making and Accession to Company Pressure. The study showed that the first three factors were reliable, whereas the fourth factor was not. The researchers claim that their factors provide a practical way of looking at ethical issues within the context of small business, as past studies appeared to be more theoretical (Hornsby et al., 1994). Perhaps 
the most enlightening contribution made by this study is refuting the common assumption that "ethics means the law" (Hornsby et al., 1994; p.13). Although there was the presence of illegal items within the study, as mentioned above, those activities did not load into one separate legal factor, thus demonstrating that small business ethical dimensions go beyond simply abiding by the law. An extension of this is to affirm that the entrepreneurs/small business owner's personal values are an important aspect of ethical decision-making (Hornsby et al., 1994).

Two additional studies were conducted using the original instrument from the Longenecker et al. (1989) study. Once more, each researcher adds another element in an effort to uncover as many aspects of is highly neglected area of business ethics. Smith and Oakley (1994) looked at the ethical values of metropolitan and non-metropolitan small business owners, while Ede, Panigrahi, Stuart and Calcich (2000) looked at ethics in small minority businesses. Both these studies challenged the validity and reliability of the survey instrument, while also stating that it is complex to empirically measure ethics in an accurate manner (Ede et al., 2000; Smith and Oakley, 1994). In Smith and Oakley's research, they explicitly outline "...that studies which use hypothetical vignettes to link managerial behaviour with various ethical issues fail to examine subjects' behaviour for consistent application and predictability" (Fritzche and Becker, 1984 as sited in Smith and Oakley, 1994; p.19). As it would be very challenging to observe the daily business activities of all the respondents, Smith and Oakley (1994) proceeded and made use of the Longenecker instrument for a cross-sectional study in light of the noted flaws. Realizing the need to purify the methodology, Ede et al. (2000) performed scale purification in

R. Coscarella 
order to establish the content validity of the scenario instrument. They requested assistance from eight business faculty members within the United States to rate each vignette, on a scale of one to ten, for ethical validity. That is, faculty participants were asked to judge if the issues listed in the vignettes truly reflected ethical dilemmas based on their own personal assessment and perception. Twelve out of the sixteen statements met the criteria of the exercise and were thus included in the study. In addition, Ede et al. (2000) performed a factor analysis on the summarized scale, which was to update the work done by Hornsby et al. (1994). Ede et al. (2000) presented the following restructured factors; Administrative Decision Making, Production Practices and Financial Practices. In order to
"...have valid and reliable measures of attitudes toward business ethics, particularly small business ethics, there appears a need to go back to basic principles of scale development rather than continue to use instruments that, while having been used previously, were not developed as a result of a rigorous development process" (Ede et al., 2000; p.141).

These two studies, Ede et al. (2000), Smith and Oakley (1994), also differed in their conclusions. In regards to age as a variable that influences ethical perceptions, Smith and Oakley (1994) concluded that a positive relationship exists between ethics and age, whereas Ede et al. (2000) report that older respondents showed less ethical views in comparison to the younger population.

Both Quinn (1997) and Vyakarnam et al. (1997) were the first to examine small business ethics within the European context and their work tends to focus on theory-building (Spence, 1999). The Quinn study explored small business owner's attitudes on two 
levels; personal ethics and business ethics. The study examined individuals (small business owners/managers) who participated in community organizations and those who did not and attempted to determine if when encountered with an ethical dilemma acted differently because of personal beliefs. The key findings from this study showed that business people did use their personal ethical attitudes when dealing with business issues. In addition, those participants that were members of external organizations (i.e. religious in nature) indicated explicit ethical concerns in terms of their business, in comparison to non-member counterparts who showed less ethical concern. This finding was later challenged by Spence and Lozano (2000) and Dawson, Breen and Satyen (2002). Both studies, from England and Australia respectively, found “...that religion was the factor most likely to have no influence on owner-managers" (Dawson et al., 2002; p.308).

Vyakarnam, Bailey, Burnett and Myers (1997) used focus groups as their investigation instrument and instigated the small business participants by asking; "Describe an ethical business dilemma you have recently faced and how did you resolve it, if at all?" Four major themes of ethical dilemmas that surfaced from the analysis are; (1) the general ethos of entrepreneurial activity, (2) the role in society, (3) conflicts of interest, and (4) issues of personality (Vyakarnam et al., 1997). Within these categories are specific ethical issues such as knowledge protection, openness and honesty, the distinction between legal and moral obligation, and the reconciliation of personal and business decisions. This study also found filters that entrepreneurs used when attempting to resolve ethical issues; (1) situational ethics, (2) quality of relationships, (3) degree of consequences, and (4) reference to external sources of advice. These issues and methods 
of resolution will be discussed in the next section. The research in this study is important because it "...goes some way to establishing what the ethical issues are for small firms" (Spence, 1999; p.168). Prior to this study there did not exist “....any research based on the perspective of small business owners to define what ethical dilemmas they face and how, if at all, they resolve them" (Vyakarnam et al., 1997; p. 1625).

However, the validity of some of the results was challenged as the information gathered for the study was through the use of focus groups. Using focus groups as the primary method of data collection in a study of this type may have significant limitations (Spence 1999). In a group setting, most individuals wish to emerge as good ethical people and thus avoid the risk of being tagged a 'bad unethical' person. Participants may be more prone to give socially desirable responses. In addition, the potential to embellish the truth when describing an ethical situation is higher because the temptation may be to entertain listeners. This was also an issue for the Welsh and Birch (1997) study that asked small business owners and owners of businesses in general how they perceived their ethical orientation. It was determined that “...small business decision-makers perceived themselves as less likely to engage in exploitative power behaviour in order to meet personal or organization objectives" (Welsh and Birch, 1997; p.47). Although realizing these potential limitations, the researchers proceeded with the study stating, "...it is still valuable, particularly in an exploratory sense for gathering hypotheses and research questions and vocabulary for future investigation in the wider context" (Vyakarnam et al., 1997; p.1629). 
Vitell, Dickerson and Festervand (2000) conducted a nationwide US survey that attempted to uncover the ethical problems, conflicts and beliefs of small business professionals. It was concluded that small business owners believe that ethical business standards are lower today than those of ten and twenty years ago, mainly due to the change in society's standards as a whole. Personal greed was also a prominent factor. An important contribution made by this study was the importance of managerial leadership in setting an ethical tone within the business. It was concluded that the ethical standards of an organization will "...only improve when top management makes it clear that ethical behaviour will be rewarded and unethical behaviour will be punished" (Vitell et al., 2000; p.22). In addition, through the use of a scenario-based questionnaire, it was observed small business owners perceived themselves as more ethical in comparison to their peers. The repeated use of this methodology has continuously shown that when asked to explicitly express ethical perceptions, the respondent usually tends to evaluate their behaviour in a more positive matter.

The Joyner, Payne and Raiborn study (2002) was the first to examine how growing small businesses establish and maintain ethical standards by looking at a specific ethical framework. Data was gathered from ten successful American companies, all meeting a set of predetermined criteria, which participated in a previous study aimed at examining venture creation and development. This information was later coded and analyzed using content analysis. Thus at the time the participants gave their responses to the study, they were not aware of the ethical undertone of the study because the questions did not explicitly make reference to ethical perceptions. This approach addressed earlier validity 
issues where participants were more likely to make socially desirable comments. It was found that all companies used both a legal compliance strategy and integrity strategy, proposed by Paine (1994), in order to transmit the entrepreneur's values throughout the business. Therefore, it was concluded that during the development and growth of new ventures, “...modeling, supporting, and rewarding ethical decisions” (Joyner et al., 2002; p.127) are especially important, thus resulting in a stronger culture throughout the organization. In addition, “...the actions of the founders were used to guide decisionmaking of the workforce for years as the firm grew." (Joyner et al., 2002; p.127) However, according to the researchers, the most important finding was that all the firms went beyond merely legal obligations demonstrating a sense of caring toward the community and all stakeholders.

The following model (see Figure 1), suggested by Morris, Schindehutte, Walton and Allen (2002), outlines how the ethical climate of an organization evolves as a new venture develops and grows. The figure shows the transition from the entrepreneur being the key ethical reference point for the firm to the establishment of a management team and an institutionalized corporate culture. This helps to reinforce the fact that while the management systems in place are a key factor in creating an ethical climate, early stage firms do not have these formal control systems in place. Again, the “...entrepreneur's personal value system becomes the organizational template for addressing issues with moral implications" (Humphreys et al., 1993; Longenecker et al., 1989; as quoted in Morris et al., 2002; p.336). This diagram also helps visualize how ethics are involved at each level of firm growth. Ethics can be found at levels 1 and 2 by the informal 
institutionalized systems of the founder. The conclusions made by the Joyner et al. (2002) study can also be implanted into this model and reinforces the finding that entrepreneurs go beyond legal compliance strategies when dealing with business ethics.

Figure 1 - Evolution in the ethical reference point as ventures grow

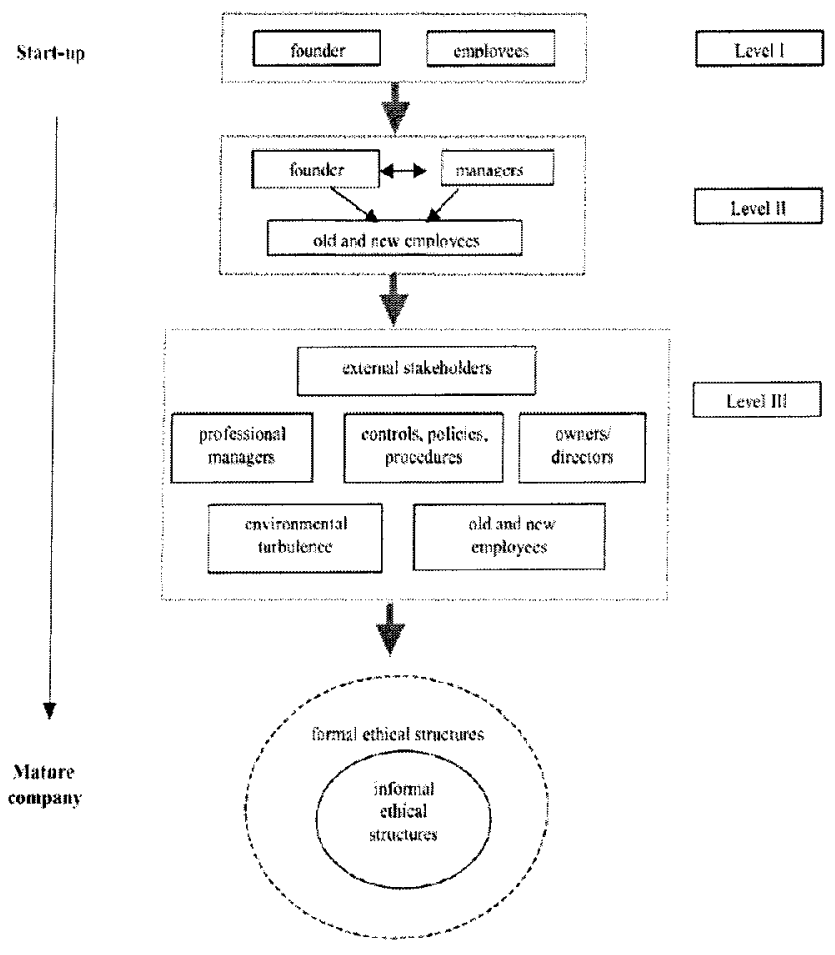

(Morris et al., 2002)

\subsubsection{Ethical Dilemmas and Resolution Framework}

Ethical conflicts occur when “...an individual perceives that his/her duties and responsibilities toward one group are inconsistent with his/her responsibilities toward some other group including ones self' (Hunt et al., 1984; p.310). This section will briefly examine what the literature has identified as being the main issues that small business owners and entrepreneurs face in their daily business operations. In addition, it will 
present a framework proposed by Vyakarnam et al. (1997) that has been used to explain what filters entrepreneurs consider to resolve these issues.

According to Morris et al. (2002), the factors of size and age of a firm attribute to the unique ethical challenges that entrepreneurs are faced with. In comparison with larger firms, small businesses are more susceptible to environmental forces due to the limited cash and increased debt capacity. It is further argued that small businesses' frequent “...over dependence on limited product/service line, and their tendency to rely on a niche customer base" (Morris et al., 2002; p. 333) can create different ethical issues for entrepreneurs. "Many firms also suffer from a relatively limited market presence, subjecting them to significant demand fluctuations, aggressive competitor forays, and lack of support from suppliers and distributors" (Morris et al., 2002; p.333).

As mentioned in the previous section, according to the Vyakarnam et al. (1997) study, the important ethical issues for small firms are knowledge protection, openness and honesty, the distinction between legal and moral obligation, and the reconciliation of personal and business decisions. These issues fit into one of the four themes that are presented in the following figure that is used in defining what constitutes an ethical issue.

- Conflict of Interests: This theme is concerned with the separation of the person from the business, when they are actually the same entity. For example, the difficulty associated with firing a family member and then having to reconcile family loyalty with business needs.

- Social Responsibility to Stakeholders: This category deals with dilemmas that describe those concerning one's role in society and the relationship 
one is meant to have within it, thus distinguishing between legal and moral obligations. For example, delayed bills payments.

- Level of Openness: This theme is related to the question of whether entrepreneurial activity is fundamentally unethical because the profit comes from the advantage one has of information. Example: Does one recommend a competitor because they are better than you at the job and you know that to be true?

- Personality Traits: This category is related to the issue of personality traits and attempting to always act professionally in a business environment. For example, firing a 60 -year-old person from the business knowing it will be hard for them to find another job and support their family in the meantime.

Figure 2 - Four Main Themes of Ethical Dilemmas

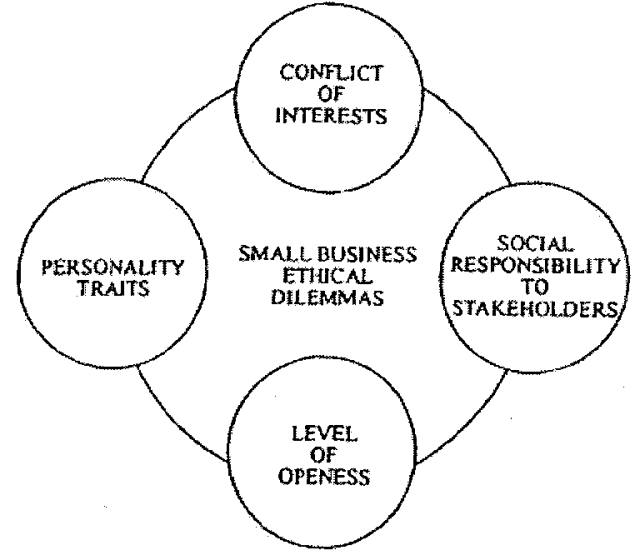

(Vyakarnam et al., 1997)

The second model proposed by Vyakarnam et al. (1997) is a web of interconnections, which may help in examining the many possible factors that are present when attempting to resolve an ethical dilemma. The figure below is complex, state the researchers, yet so is ethics. The study was not able to determine one major factor that small business owners use in resolving the issue, arguing that there are "...many subtle and explicit 
connections" that have been demonstrated in the following figure (Vyakarnam et al., 1997; p.1635). However, it does help visualize the many potential elements considered in ethical decision-making.

Figure 3 - Web filters used to resolve ethical dilemmas

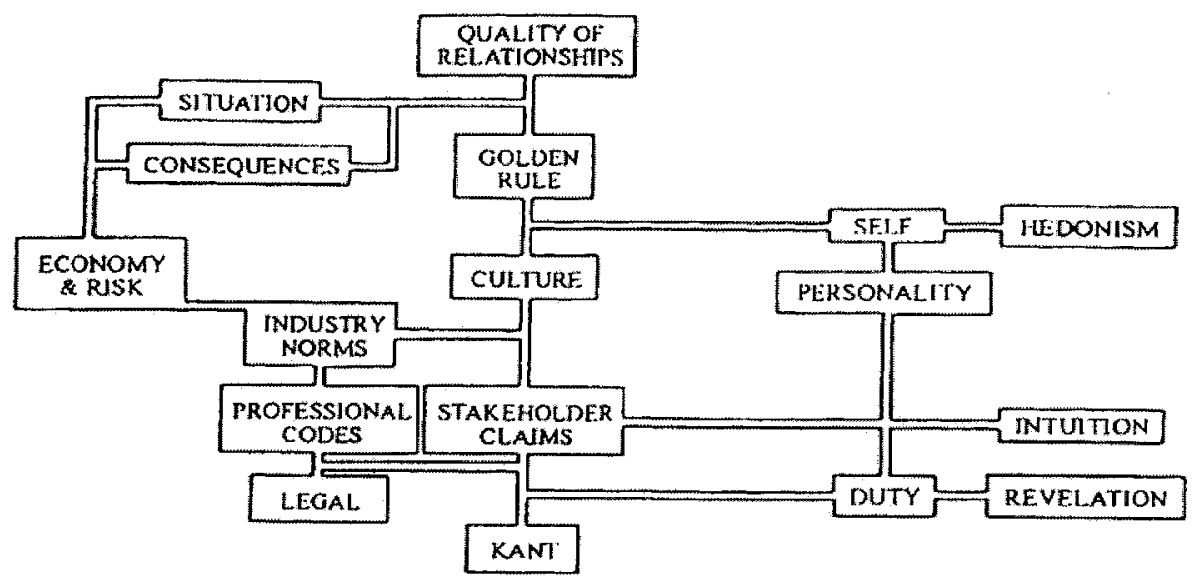

(Vyakarnam et al., 1997)

There exists only one additional study that explores the specific ethical issues encountered by American small business owners. Vitell, Dickerson and Festervand (2000) asked 153 US small business professionals if they had experienced "a conflict between what was expected of them as a business executive and their own personal ethics relative to both various stakeholder groups and ethical situations" (Vitell et al., 2000). It was concluded that the majority of the ethical issues and conflicts that arise in a small business are due to relations with customers and employees, especially with regard to honesty in contractual agreements and human resources decisions. The study did not evaluate the strategies that these business professionals employ in order to avoid or mitigate the aforementioned dilemmas. 


\subsubsection{Managerial Strategies Used to Direct Ethical Issues}

In her research, Paine (1996) identifies two managerial strategies that managers use to direct the decisions and policies within their organization; the legal compliance strategy and the organizational integrity (values-based) strategy. "Most managers are choosing either a legal compliance strategy or an organizational integrity strategy to support ethics in their companies" (Paine, 1996; p.212). Thus far, this framework has been applied solely to the research done on corporate ethics, except for the study conducted by Joyner et al. (2002) on ethics and growing firms, which is outlined in the previous sections.

These strategies are important because managers need to acknowledge their role in influencing organizational ethics or they may find themselves at risk of liability within the tough legal environment (Joyner et al., 2002; Paine, 1994). These strategies are also applicable to small businesses and give entrepreneurs a starting point when looking at business ethics. Having in place such strategies can aid in preventing ethical slips and allows room for moral thoughts and behaviours. When these strategies become mainstream within an organization, the ethical framework works its way within the business and thus is no longer viewed solely as a burden. According to Paine, these two strategies differ on five different elements; ethos, objectives, leadership, methods and behavioural assumptions. Each element will be discussed further here.

The legal compliance strategy is externally driven and views ethics as boundaries that must not be crossed. This strategy looks at ethics as something that must be done. The primary objective of this strategy is to prevent illegal conduct from taking place and 
positions lawyers at the forefront of leadership. The rules presented by this strategy stress the set of laws that employees must not violate and make use of "...stepped-up penalties to enforce these rules." (Paine, 1996; p.212) The behavioural assumption made by this strategy is based on the deterrence theory. That is, "manipulating the costs of misconduct" (Paine, 1996; p.212) to avoid unethical problems.

Every organization needs to stay within the boundaries established by the law. However, there are many limitations when a company decides to solely follow the legal compliance strategy. Compliance is not always receptive to the daily concerns of managers and employees. The law tends to look backward, thus for new innovative companies, the law cannot help as there is no law in place yet to respond. Secondly, most employee complaints do not deal with criminal misconduct within the organization. The protests usually deal with the 'grey areas' of employee treatment. By simply following the legal compliance strategy, many of the problems encountered by employees and not addressed (Paine 1996).

The next strategy is the organizational integrity strategy.

"While the organizational integrity strategy fully acknowledges the importance of compliance with the law, its aim is to achieve right conduct in general. Companies that adopt an organizational integrity strategy are concerned with their identity - who they are and they stand for - and how they conduct internal and external affairs." (Paine, 1996; p.212)

This strategy views ethics as a tool to guide choices and decisions, where the company selects its own business principles at the individual and company-wide level. The 
objective is to attain ethical conduct at all levels of the business, without it necessarily being required by the law. The organization's managers are the ones that lead, while receiving assistance from lawyers and other experts. This is also true of entrepreneurs and their influence on ethical culture of the business environment, although many resist the notion that the organization influences individual actions due to fear of being held responsible of misconduct (Joyner et al., 2002; Paine, 1994). This strategy allows a company to "treat ethics as a steering mechanism rather than the brake" (Paine, 1996; p.212). Ethics permeate every aspect of the business; its systems, decision-making process and the management team. The behavioural assumption here is that employees are motivated not only with material self-interest, but have a more in-depth set of requirements.

Table 1 - Paine's Ethical Framework

\begin{tabular}{|c|c|c|}
\hline Strategy Type & Reason for Strategy & Actions Within Strategy \\
\hline $\begin{array}{l}\text { Legal Compliance } \\
\text { Strategy }\end{array}$ & $\begin{array}{l}\text { Adherence to the letter of the law. } \\
\text { Desire to avoid public outrage, } \\
\text { loss of public trust and a tarnished } \\
\text { image. }\end{array}$ & (1) Follow the letter of the law \\
\hline Integrity Strategy & $\begin{array}{l}\text { Adherence to the spirit of the law. } \\
\text { Desire to avoid exploitation of } \\
\text { loopholes within the law }\end{array}$ & $\begin{array}{l}\text { (1) Communicate values and } \\
\text { commitments } \\
\text { (2) Personally committed } \\
\text { management } \\
\text { (3) Integration of values into } \\
\text { strategic decision-making } \\
\text { (4) Structure supports and } \\
\text { reinforces principles } \\
\text { (5) Managers trained to use } \\
\text { values and commitments }\end{array}$ \\
\hline
\end{tabular}

(Adopted from Joyner, Paine and Raiborn, 2002) 


\subsection{Canadian Small Businesses and Exporting}

In Canada, exporting is an important element of the economy accounting for 40 percent of the Gross Domestic Product (GDP) in recent years (Statistics Canada 2004). In order to remain competitive in today's business environment, small businesses are looking to the global economy to grow and gain from international opportunities (Labbe, 1994). As previously mentioned, small businesses account for 97 percent of all Canadian organizations, employing 56 percent of the Canadian population (Business Register of Statistics Canada, 2005). In 2002, it was concluded that 85 percent of Canadian exporters were small businesses and 20 percent of the total value of the exports were attributed to small firms. Small businesses “...do make a significant contribution to Canada's exports" (Statistics Canada, 2004). On the other hand, the proportion of small firms that export is lower than the proportion of small businesses in the overall economy. According to Statistics Canada (2004), 1.4 percent of small ${ }^{3}$ businesses export, in comparison to 27 percent of medium ${ }^{4}$ businesses and 37.7 percent of large ${ }^{5}$ businesses participate in exporting.

\subsubsection{Exporting Barriers/Challenges}

The low rate of small business exporting can be attributed to the fact that small businesses have been reluctant to partake directly in international business. This can potentially be a result of a lack of information, contacts, skills and resources by small businesses to compete in a marketplace dominated by large businesses.

\footnotetext{
${ }^{3}$ All businesses with fewer than 100 employees (Definition used by Industry Canada)

${ }_{5}^{4}$ All businesses employing between 100 and 499 people (Industry Canada)

${ }^{5}$ All businesses employing more than 500 people (Industry Canada)
} 
According to Bagchi-Sen (1999), problems encountered by Canadian exporters can be divided into two broad categories, internal barriers and external barriers. His research thoroughly summarizes the concerns that the majority of small businesses who export face. The following table outlines potential issues.

Table 2 - Internal and External Barriers to Exporting

\begin{tabular}{||l||l||}
\hline \hline \multicolumn{1}{|c|}{ Internal Barriers } & \multicolumn{1}{c|}{ External Barriers } \\
\hline \hline - Financial Requirements & - Cultural Differences \\
- Lack of Operating Capital & - Licensing Requirements \\
- Lack of In-House Expertise & - Right of Establishment \\
- Risk Willingness & - Immigration Issues \\
- Ineffective Management & - Government Controls/Regulations \\
- Management Time Requirements & - Rising Cost of Production Inputs \\
- Poor Labour-Management & - Employee Recruitment Problems \\
Relations & \\
- Out-Dated Plant and Equipment & - Shortage of Production Inputs \\
& - Declining Demand for Product \\
& - Strong Domestic Competition \\
& - Strong Competition from Foreign \\
\hline \hline
\end{tabular}

(Adapted from Bagchi-Sen, 1999)

Bagchi-Sen (1999) states that there is also a difference in how small businesses with high and low export orientation (i.e. success and unsuccessful exporters respectively) evaluate export barriers. The only external barrier differentiating between firms with high and low orientation to exporting is the competition from foreign producers. The significant internal barriers pertain to the lack of scale economies, in-house expertise, operating capital, finances and management time.

Realizing the importance of small business exporting to the economy, a series of initiatives have been established by the Canadian public sector in an attempt to aid small 
firms to excel in the international business environment. The following issues have been identified by small businesses as areas where they could benefit from governmental assistance: accessing clear, comprehensive information and intelligence on international businesses; improving support services to small businesses; strengthening partnerships to set priorities and make better use of existing infrastructure; obtaining appropriate financing (Small Business and Policy, 2003). Again, the issues overlap those mentioned in Table 2.

\subsubsection{Women Entrepreneurs and Exporting}

The subject of women as entrepreneurs has created increased interest in many areas of the world. The Organization for Economic Cooperation and Development (OECD), the Asia-Pacific Economic Cooperation and the European Union have engaged in policy discussions regarding women entrepreneurs. For example, in 1997 and 2000 the OECD hosted two policy forums on women's entrepreneurship with the objective to identify how to increase the participation level of women in business ownership (OECD Conference, 2000).

Women often face structural barriers restricting their full participation in economic activity and some have said to be gender related (OECD, 2000). If women are to have equal opportunity to engage in entrepreneurial activity, then barriers have to be removed. In a recent study conducted on Target Polices and Measures by the OECD (2000), major policy initiatives were found that focused on the development of women entrepreneurs in seven of the ten countries that were researched. Canada and the United States were the most advanced in this area. It was also noted that Canada and the United States have the 
highest levels of female entrepreneurship, 58 and 60 percent respectively, in comparison with eight other countries; Australia, Finland, Ireland, Netherlands, Spain, Sweden, Taiwan and the United Kingdom.

In Canada, the government realizes that women are important in the business environment and the economic growth potential to be achieved from the higher levels of entrepreneurial business from women. According to a study conducted by CIBC (2004), there are 800,000 women entrepreneurs in Canada. The growth rate of women-owned businesses is rising 60 percent faster than those run by men (CIBC, 2004). However, on average women owned firms are smaller, grow more slowly, are less likely to employ others in the business and are less likely to export.

Orser, Riding and Townsend (1999) conducted a study, which examined the characteristics, attitudes and issues of Canadian women business owners that exported in Canada. Challenges that women exporter and export planners (export ready having exported but not yet established repeat customers) faced are similar to the issues encountered by all Canadian exporters. The main barriers identified were; foreign exchange risk, lack of general exporting information, tariff barriers, not being taken seriously and obtaining licensing and bonding. Both groups of participants stated that marketing barriers were significant as well. They include; the cost of developing a new market, setting up effective distribution channels, finding local partners, obtaining foreign market information and identifying and dealing with the foreign government regulations. In addition, personal barriers were also mentioned, such as family 
responsibilities, lack of specific skills, personal safety risks abroad and personal health risks (Orser et al., 1999). Another interesting finding from their study challenges the above stereotype profile of women entrepreneurs. It was found that women entrepreneurs export early in the life of the firm. This goes against the model that firms begin small and grow in their local market and later expand into the international marketplace.

\subsection{Critique of the Literature}

The following is a brief critique of the literature reviewed above. Hypothetical vignettes have been used in many studies (i.e. Longenecker et al., 1989; Humphreys et al., 1993; Hornsby et al., 1994; Smith and Oakley, 1994; Vitell et al., 2000) to measure managerial ethical behaviour and perceptions, but some contend that they failed to evaluate the manager's (entrepreneurs') true behaviour (Joyner et al., 2002; Paine 1994). Fritzche and Becker (1984) argue "...this flaw is one reason scholars find it difficult to understand the relationship of an individual's personal value system and the factors which influence his or her business decisions" (Smith and Oakley, 1994; p.19). Thompson and Smith (1991) have been critical of many studies conducted on small business ethics due to different 'small' firm sizes, limited geographic representation, small sample sizes and lack of statistical validity and analysis. For instance, when defining a small business, many American studies have used varying definitions based on the number of employees. They range from fewer than 35 employees (i.e. Wilson, 1980) to fewer than 1000 employees (i.e. Dunfee et al., 1991; Robertson, 1991). An organization with ten employees can be quite different from a firm that employs hundreds. In addition, certain studies make reference to specific sectors (Hornsby et al., 1994) while other studies (i.e. Brown and 
King, 1982) do not refer to any particular sector. The final critique is that none of the studies discussed above have been replicated for validity and reliability. Although the methodological tools (i.e. the Longenecker et al., 1989 instrument) have been used several times, not a single study has been replicated with a larger sample size or different geographical location.

Given the critiques above, it is evident that additional studies are required and that the previous ones require further validation through replication. However, there has been some consistency in the studies because the researchers have realized the difficulty of measuring ethics and have avoided the tendency to over analyze the information obtained (Thompson and Smith, 1991) because it is evident that future research is required in order to improve the robustness of the overall literature. 


\section{Research Questions}

The purpose of this study was to review business ethics in small organizations, specifically identifying and examining the ethical issues that confront exporting entrepreneurs. The study focused solely on the Canadian women owned small businesses.

This thesis undertook the following research questions with increased emphasis on the first two questions:

-What ethical issues are encountered by women entrepreneurs when exporting?

- Are these issues similar to those found in past studies and do they fit into any of the models available in the literature? (i.e. Morris et al., 2002; Vyakarnam et al., 1997; Mayo et al., 1991)

- How, if at all, do entrepreneurs attempt to resolve these issues?

- Are there any indications of managerial strategies (i.e. legal compliance and/or organizational integrity) reflected in the actions that entrepreneurs take to mitigate and/or resolve ethical issues?

Hypothesis 1 - Reflecting on what is available in the literature on small business ethics and exporting, it was expected that the women entrepreneurs would experience a series of issues, ranging from political and cultural dilemmas to customer and employee based ethical issues. 
Hypothesis 2 - It was also expected that the respondents would in fact attempt to resolve these issues, yet without the use of institutionalized systems. Based on the literature, small businesses rarely have formal ethical structures in place by which to base and aid decision-making.

The following sections will outline the methodology followed in order to the reach the findings that are explained in Chapter 5 of this thesis. 


\section{Research Methodology}

This chapter examines the methodology used to respond to the research questions discussed in the previous chapter. The data source, sample and instrument used in the analysis are outlined, followed by a discussion of the analytical methods that were utilized to analyze the data received.

\subsection{Data Source and Sample}

A majority of the studies previously conducted on business ethics explicitly asked ethically based questions. That is, the participants were aware that their ethical perceptions, experiences and behaviours were being evaluated. Brown and King (1982) site Kohlberg (1964) as stating, “...that most people tend to rate their own ethical standards higher than their actual choices imply. Presumably, such a phenomenon has something to do with people's desire to enhance their feelings of self-esteem" (Brown and King, 1982; p.13).

In addition, it has been concluded by the research community that researchers will need to rely on personal interviews when researching ethics, as "...data collection via mail questionnaires will not overcome the self-reported data problems nor facilitate researchers' insight into social responsibility (ethical) issues at the operating level" (Thompson and Smith, 1991; p.6). As well, studies have been criticized for not focusing on a particular sector or group of entrepreneurs (Thompson and Smith, 1991). 
For this study, therefore, the findings will draw on a re-analysis of a sample used in previous research conducted by Orser et al. (1999), Beyond Borders - Canadian Businesswomen in International Trade. Joyner et al. (2002) also used this strategy of reevaluating existing data in order to mitigate a key concern of collecting data without leading the subjects to their answers. The rationale for using the Orser et al. (1999) data set is that it avoids the difficulties mentioned above. Summarizing, (1) the Orser et al. (1999) study did not explicitly ask ethics related questions, (2) the final data was collected via personal interview, not via questionnaire, (3) the sample consisted of Canadian women entrepreneurs who export, thus focusing the study to a particular group of participants, and (4) the sample included respondents from across Canada (from the Western Provinces, Ontario, Quebec and the Atlantic Provinces), thus addressing the criticism of Thompson and Smith (1991) that past studies were limited in geographical representation.

The study, Beyond Borders - Canadian Businesswomen in International Trade, was a large Canadian initiative funded by both private and public sectors agencies, representing a first of this magnitude at a national and global level. At the time of the research, no other study had incorporated such a different array of research methods. A number of important individuals within the academic and public sector environments participated in the creation of this report, including Dr. Barbara Orser (Carleton University/University of Ottawa), Dr. Allan Riding (Carleton University/University of Ottawa), Dr. Eileen Fischer (York University), Dr. Rebecca Reuber (University of Toronto), Ms. Joanna Townsend (Director of the Small and Medium Enterprise Department for the Department of Foreign 
Affairs and International Trade) and Ms. Sue Hooper (Asian Pacific Foundation of Canada). The information from this study served as an aid to help guide the Department of Foreign Affairs and International Trade (DFAIT) in improving and devising programs and policies for those women business owners that participate in exporting. The study was a great success and an excellent and accurate data source.

The Orser et al. (1999) sample included small and medium sized businesses and it was divided into two main groups; active exporters and export planners ${ }^{6}$. The demographics of the firms in the previous study fit the parameters set for this study. "Active exporters had an average of 24 employees and achieved an average annual sales volume of $\$ 250,000-\$ 500,000$, while export planners reported an average of 4 employees and achieve an annual sales volume of $\$ 100,000-\$ 250,000 "$ (Orser et a1., 2004; p.9). Therefore, although medium sized businesses were also targeted in the original study, the profile of the firms interviewed was referred to as small firms (Orser, et al. 1999), thus making the data relevant for this thesis on small businesses. Orser et al. (1999) stated that " 42 percent of active exporters and 68 percent of export planner report annual sales of less than $\$ 250,000$. These are indeed very small firms" (Orser et al., 1999; p.9).

The sample for the study was obtained in three stages; (1) a list of 1,452 contacts was provided by the Department of Foreign Affairs and International Trade. All eligible ${ }^{7}$

\footnotetext{
${ }^{6}$ Active exporters are defined as firms that currently export and make repeat sales to multiple foreign customers, or have been exporting for more than two years. Export planners (that is, export-ready), are defined as businesses that have made some initial export sales but have not established repeat customers, and who have committed to developing the export market within the next 12 months.

${ }^{7}$ Eligibility criteria: business employed fewer than 500 employees; exported or were planning to export; and included at least one owner who was a woman who was actively engaged in the direction of the business, and who held authority to make business and export decisions
} 
firms went through an initial screening questionnaire and were sent faxed surveys. (2) A total of 188 responses were received in the first round. A second attempt at data collection was carried out, adding 66 more respondents to the sample. (3) Telephone interviews were conducted with 54 of the participants that responded back to the initial survey and who agreed to participate. These 54 interviews were re-analyzed in order to answer the research questions set forth in this particular thesis.

\subsection{Research Instrument}

The telephone interview that was administered to 54 women small business owners consisted of four sections (see Appendix B). Section one asked respondents to reflect back before they began exporting and why the original decision to export was made (which is an average of 5.5 years). Respondent recollection could be a possible limitation, however the women did in fact give specific examples, showing that they did in fact remember the challenges that they were encountered with. Section two asked participants to reflect on the early days of exporting and to outline any challenges encountered and if they made use of public or private sector programs. The third section of the interview asked questions pertaining to current exporting issues and how they are dealing with the issues. The final section asked respondents to describe business strategies used when entering markets outside of Canada and other exporting strategies.

Personal and firm demographics were collected prior to the telephone interview through a screening interview. Those women that indicated that they would be willing to participate in the second part of the research stage were contacted for this telephone interview. 


\subsection{Analysis}

The data collected from the initial study by Orser et al. (1999) was recorded and transcribed. For this thesis, the interview scripts were divided into two categories; export planners and active exporters. Each interview was reviewed individually for indications of ethical issues. Ethics have been repeatedly identified as something subjective (Spence and Loranzo, 2000; Conill, 2000) and complex to empirically measure in an accurate manner (Ede et al., 2000; Smith and Oakley, 1994). It is often difficult to draw the lines of what is considered to be completely good and completely bad, or what is partially good and partially bad. Many studies within the literature have not used clear criteria when defining what is ethical and what is unethical. The following chart outlines how some researchers have analyzed ethics. Each researcher employed a different method of evaluation and a concrete definition or set of guidelines for evaluating ethics have yet to be consistently used or agreed upon by the research community.

Table 3 - Analysis of Ethics in the Literature

\begin{tabular}{||l||l||}
\hline \multicolumn{1}{|c|}{ Study } & \multicolumn{1}{|c|}{ Analysis } \\
$\left(\begin{array}{l}\text { Longenecker et al. } \\
(1989)\end{array}\right.$ & $\begin{array}{l}\text { - used scenario-based questionnaire that depicted mostly illegal } \\
\text { business scenarios } \\
\text { - asked respondents directly and classified responses into general } \\
\text { categories }\end{array}$ \\
\hline Mayo (1991) & $\begin{array}{l}\text { - explicitly asked what participants perceived as ethical, based } \\
\text { on subject's perceptions through the use of a questionnaire }\end{array}$ \\
\hline Humphreys et al. (1993) & $\begin{array}{l}\text { - scenario-based, participants asked to report what they felt as } \\
\text { being ethical behaviour }\end{array}$ \\
\hline Hornsby et al. (1994) & $\begin{array}{l}\text { - used Longenecker et al. (1989) instrument } \\
\text { - original scenarios were grouped into categories and } \\
\text { participants were asked to report if the grouped scenarios } \\
\text { represented ethical behaviours }\end{array}$ \\
\hline Vyakarnam et al. (1997) & $\begin{array}{l}\text { - used focus groups and explicitly asked subjects to speak about } \\
\text { ethics based on their perceptions and experiences }\end{array}$ \\
\hline \hline
\end{tabular}




\begin{tabular}{|l||l||}
\hline \multicolumn{1}{|c|}{ Study } & \multicolumn{1}{|c|}{ Analysis } \\
\hline \hline & - prominent themes were identified by the researchers based on \\
their perception
\end{tabular}

In the Mayo (1991) study specifically, the dilemmas were classified into one of 11 different categories (9 ethical problems, miscellaneous and no ethical problems encountered). These categories, which were also discussed above in Chapter 2, are Bribery, Government interference, Customs clearance, Transfer of funds, Cultural/business differences, Technology/copyright theft, Pricing, Immoral entertainment, Product use, No ethical problems and Miscellaneous. The following table describes the ethical problems in detail that Mayo discovered in his research. 
Table 4 - Ethical Problem Categories in International Marketing

Bribes and/or questionable payments - This category included any response that directly identified the issue of paying bribes or questionable commissions or making payments which would not be legal or ethical in the United States.

Political issues and/or government intervention - This category included any response which identified problems created by political issues/policies or direct government intervention or sanctions. Included here would be problems caused by either the United States government or the government of a foreign country.

Customs clearance - This category included any request or demands for special payment or documentation whose intent was to circumvent customs regulations.

Questionable transfer of funds - This category deals with the illegal or questionable transfer of funds out of the country or to unusual places, people, or accounts for any purpose, including avoiding taxes or foreign country's regulations.

Cultural and/or business practice differences - This category included any response that relates to problems which arise as a result of trading with markets having cultural and/or business practice differences. Some of these may not be ethical issues, but simply problems that results when dealing with others who have different ways of conducting their business and private lives.

Technology theft and copyright infringement - Given differences in legal systems and/or ethical values, some foreign firms do not honour United States patent and copyright legislation. This category included any response which identified copyright infringement and/or technology theft by a foreign firm.

Pricing practices- This category included pricing policies and structures that represent unfair and/or unethical practices toward competition, consumers and/or intermediaries.

Immoral entertainment - The norms in some countries allow or even encourage the provision of forms or types of entertainment which would not be allowed in the United States. This category included all responses which refer to such immoral entertainment being provided or expected.

Questionable product use - This category included al response which identified the improper, dangerous, and/or non-recommended use of a firm's product (s) by foreign consumers.

No ethical or moral problems - This category included all responses which indicated that no ethical problems were encountered in international trade.

Miscellaneous - This category included all responses which did not fit into any of the other more specialized categories.

(Source-Mayo, 1991; p.56)

It was concluded by Mayo (1991) that these were the ethical problems encountered by

U.S. Small Businesses in International Marketing. The frequency in which these ethical

problems emerged in this current research were noted and are detailed below in the

following chapter. The ethical dilemmas encountered in the re-analysis of the 54 
interviews were also grouped and it was also attempted to group the dilemmas into the model proposed by Vyakarnam et al. (1997) depicting the four main themes of ethical dilemmas; Conflict of Interest, Social Responsibility to Shareholders, Level of Openness and Personality Traits. These are also used in defining what constitutes an ethical issue, according to Vyakarnam et al. (1997).

In order to analyse the data for this thesis, the following criteria was used to determine if the difficulties encountered by the participants were ethical in nature. This criteria was inspired by the academic definitions of ethics; (1) the action or event benefits one group and by doing so puts the other group at a disadvantage, and/or (2) the responsibilities and actions toward one group are inconsistent with the responsibilities and actions toward some other group, and/or (3) the action is illegal. As well, a search for key words (similar to those used by other researchers such as Spence and Lozano, 2000 and Joyner et al., 2002) was performed in order to reinforce the existence of ethical scenarios, through the existence of common ethical vocabulary.

In the second portion of the re-analysis, resolution strategies were examined. Again, indications of the filters proposed by Vyakarnam et al. (1997) (see Section 2.2 Figure 3) were observed, as well as any managerial strategies discussed by Paine 1994 using mainly content analysis. The information was coded using Q.S.R Non-numerical Unstructured Data Indexing, Searching and Theorizing (Q.S.R. NUD*IST), an analytical "...tool that allows identification of relevant themes and issues from narrative text (Orser et al., 2004; p.7). 
Summarizing, each interview was reviewed on an individual basis and examined using the criteria outlined above and with the use of keyword identification. The recollected scenarios/examples were then grouped into specific categories, following the template used in the Mayo (1991) study. The interviews were also examined for evidence of resolution strategies taken by the small business owners when attempting to solve these ethical challenges. 


\section{Research Findings}

Chapter five presents the major findings of this research on women exporters and the ethical issues encountered. The goal of this section is to outline the sample demographics of the participants examined and to present the results of the analysis related to the research questions outlined in Chapter 3.

This chapter is divided into four sections. Section 1 outlines sample demographics, including profiles of the respondents and the firms. The second, third and fourth sections outline the results associated with the proposed research questions.

\subsection{Sample Demographics}

The following two sub-sections outline the profiles of the total respondent group $(n=54)$, which participated in the Orser et al. (1999) study. Both respondent and firm demographics are provided separately.

\subsubsection{Profile of the Respondents}

As previously mentioned, the sample employed in the Orser et al. (1999) study included respondents from across Canada. The following chart outlines the specific breakdown.

Table 5 - Geographic Representation of the Participants

\begin{tabular}{|c|c|c|}
\hline Canadian Region & $\begin{array}{c}\text { Number of Small Business } \\
\text { Respondents }\end{array}$ & $\begin{array}{l}\text { Proportion of Survey } \\
\text { Respondents (\%) }\end{array}$ \\
\hline Western Provinces & 17 & $32 \%$ \\
\hline Ontario & 25 & $46 \%$ \\
\hline Quebec & 5 & $10 \%$ \\
\hline Atlantic Provinces & 7 & $12 \%$ \\
\hline Northern Territories & 0 & $0 \%$ \\
\hline
\end{tabular}


Although this differs from the general small business population described by Statistics Canada (Business Register, 2001) in which 32 percent of firms are located in Ontario, 24 percent in Quebec, 35 percent in the Western Provinces and 9 percent in the Atlantic region, the respondents do span across Canada, thus demonstrating opinions that are not limited to just one specific geographical area (i.e. one city, province) and addressing the research limitation described by Thompson and Smith (1991).

Both active exporters and export planners show similar demographics. The sample consisted of women that were mostly born in Canada ( 75 percent), where 25 percent immigrated to Canada from various countries. In terms of education, 28 percent have a graduate degree, 43 percent have a college or university degree, and 9 percent have a high school diploma. Therefore, it can be said that the respondents were highly educated, as over 70 percent of the sample completed some type of post-secondary education. Of the women interviewed, 60 percent speak one language, 28 percent are bilingual and 12 percent speak three or more languages. Lastly, 88 percent of the women respondents are the original founders of their small business, as opposed to 9 percent who purchased it and 3 percent that inherited the business and now have ownership.

Worth noting, however, is the largest demographic difference between the active exporters and the export planners. The following chart demonstrates the differing years of business experience between the two groups. 
Table 6 - Active Exporters and Export Planners Business Experience

\begin{tabular}{||l||c||c||}
\hline \hline & $\begin{array}{c}\text { Active Exporters n=40 } \\
\text { (average years of } \\
\text { experience) }\end{array}$ & $\begin{array}{c}\text { Export Planners n=14 } \\
\text { (average years of } \\
\text { experience) }\end{array}$ \\
\hline \hline Overall business experience & 15 & 11 \\
\hline Export-related experience & 8 & 3 \\
\hline Business ownership experience & 9 & 6 \\
\hline
\end{tabular}

As exporting is usually linked with growth (Pope, 2002; Taper, 1995) the numbers reflect that indeed those firms that have been around longer are more likely to export more. The active exporters have more than double the experience exporting than the export planners, which may later aid in explaining the differences in ethical issues between the two groups.

\subsubsection{Profile of the Small Businesses}

The businesses represented in this study are quite small in comparison to the average small business in Canada at the time the data was collected, where the average national revenue for small business was $\$ 285,000$ (Insights, Statistics Canada, 1999). The firms managed by active exporters realized annual sales of $\$ 250,000$ - $\$ 500,000$ and averaged a staff of 24 employees. On the other hand, export planners realized annual sales of $\$ 100,000$ - \$250,000 and had an average workforce of 4 employees. Overall, 42 percent of active exporters and 68 percent of export planner reported annual sales of less than $\$ 250,000$.

In Canada, it is evident that those small businesses that actively export are larger and through their investments in exporting are also achieving greater financial earnings. The 
majority of the firms represented were older than 6 years (43 percent). The following table outlines the sector in which the women-owned businesses operate.

Table 7 - Sectoral Distribution of Respondent Firms

\begin{tabular}{|c|c|}
\hline Sector & Distribution Percentage (\%) \\
\hline \multicolumn{2}{|l|}{ Manufacturing } \\
\hline Food and Beverage & 6 \\
\hline Textiles and Clothing & 11 \\
\hline Wood Products, Furniture and Fixtures & 6 \\
\hline Paper, Printing and Publishing & 12 \\
\hline Primary Metals & 1 \\
\hline Machinery & 1 \\
\hline Transportation Equipment & 2 \\
\hline Electrical and Electronic Products & 3 \\
\hline Non-Metallic Mineral Products & 12 \\
\hline Chemicals and Chemical Products & 2 \\
\hline Other Manufacturing (including Arts, Crafts, Gifts) & 20 \\
\hline Total Manufacturing & 76 \\
\hline Total Retail and Wholesale & 2 \\
\hline \multicolumn{2}{|l|}{ Services } \\
\hline Tourism and Recreational Services & 2 \\
\hline Consulting and Business Services & 15 \\
\hline Legal, Educational and Technical Services & 5 \\
\hline Total Services & 22 \\
\hline
\end{tabular}

(Source-Orser et al. 1999, p. 11)

The women respondents were mainly involved in manufacturing, specifically producing arts, crafts and gifts. The remaining 22 percent of the businesses were involved in the services sector. Ten percent of the businesses sold both products and services. This is opposite to the overall profile of small businesses in Canada, where the majority $(78.1 \%)$ of the firms are involved in the services sector, whereas the goods-producing sector represents $21.9 \%$ of small businesses (Business Register of Statistics Canada, 2002). 
In terms of exporting their products and services, the United States is the dominant export market ( 74 percent of firms), 60 percent conduct exporting activities with Asia, 58 percent of the firms with Europe, and 30 percent with Central and South America (including Mexico and the Caribbean).

\subsection{Results Associated With Research Questions 1 \& 2}

- What ethical issues are encountered by women entrepreneurs who engage in exporting activities?

- Are the ethical issues discussed in question 1 similar to those found in past studies and do they fit into the proposed models available in the literature?

In order to answer the above questions, each interview was analyzed individually in search of ethical issues, according to the criteria explained in Chapter 4 and is summarized below for the convenience of the reader.

(1) the action or event benefits one group and by doing so puts the other group at a disadvantage, and/or

(2) the responsibilities and actions toward one group are inconsistent with the responsibilities and actions toward some other group, and/or

(3) the action is illegal.

In addition, a basic word search, inspired by Spence and Lozano (2000) and Joyner et al. (2002), was performed. The words 'honesty', 'trust', and 'responsibility' were encountered 8,4 , and 9 times respectively. These words can be grouped into the quality of relationships and communication with other people (Spence and Lozano, 2000). The respondents did make frequent mention to the importance of maintaining quality 
relationships with customers, employees and international suppliers. This is explained in more detail in Section 5.4, where the managerial strategies are looked at in more detail.

The phrases 'codes of ethics', 'business ethics' or 'social responsibility' were not encountered in any of the interviews. Corporate citizen, however, was found in one interview. This may be attributed to the fact that the overall tone of the interview was not about ethics and the associated vocabulary. Being that the respondents were not probed to speak directly about business ethics, the probability of them using the vocabulary diminishes, especially since "...their reference to ethics are (often) embedded in other qualifying terms" (Spence and Lozano, 2000; p.47). Not only were the positive words not frequently used, but the negative words (such as cheating, rip off people, etc.) were not found. However, many respondents did describe at length situations where they were mistreated or witnessed unjust behaviour. These incidences are explained throughout the remaining section of the chapter.

Common themes were identified among the interviews and as the ethical issues match the issues identified by other researchers, it was decided that the problems should be classified into the categories originally proposed by Mayo (1991). Mayo did not specify how many respondents of his sample $(n=-192)$ were in fact women. Again, these categories were chosen because this is the only study to incorporate the element of internationalization into business ethics research. 
The table below explains each category and examples for each are also provided. The issues presented met one or more of the criteria to be included in the category and matched the definition followed by Mayo (1991). It is important to keep in mind that these are excerpts of the whole text, and that the entire text is needed to get the true meaning of what is being explained. However, the essence of the responses is captured here. Also, an electronic key word search in Nud*Ist was performed for the presence of these specific terms to aid in the identification.

Table 8 - Explanation of Ethical Issues

\begin{tabular}{|c|c|c|}
\hline Ethical Issue & Description & Example \\
\hline $\begin{array}{l}\text { Gender and } \\
\text { equity }\end{array}$ & $\begin{array}{l}\text { Any response that made } \\
\text { mention of different } \\
\text { behaviour or treatment given } \\
\text { to a respondent due to their } \\
\text { gender. }\end{array}$ & $\begin{array}{l}\text { "I had to hire a man, basically a business } \\
\text { consultant in order to sort of make it look } \\
\text { a little bit more like there's men involved } \\
\text { rather than just women." } \\
\text { "(Louis said) of course a husband had to } \\
\text { make more than his wife, so he was } \\
\text { giving him an increase to } \$ 65 . " \\
\text { "So I would say that the issues around } \\
\text { equity are more exaggerated in other } \\
\text { countries that are not as proactive around } \\
\text { equity as we are in Canada." } \\
\text { "I think Barbados is a fairly advanced } \\
\text { country but even there the consultants } \\
\text { coming in from the outside, there is less } \\
\text { creditability if you're a woman than if } \\
\text { you're a man." }\end{array}$ \\
\hline $\begin{array}{l}\text { Cultural/business } \\
\text { differences }\end{array}$ & $\begin{array}{l}\text { Any problems which arise } \\
\text { while interacting with people } \\
\text { of other countries and } \\
\text { cultures. } \\
\text { (Sometimes it is difficult to } \\
\text { draw the lines between what }\end{array}$ & $\begin{array}{l}\text { "It's a very intriguing prospect but I want } \\
\text { to make sure that it's legit." (reference to } \\
\text { doing business with Greece and the } \\
\text { difference in business operations that } \\
\text { include performing activities that are } \\
\text { considered illegal in Canada) }\end{array}$ \\
\hline
\end{tabular}




\begin{tabular}{|c|c|c|}
\hline Ethical Issue & Description & Example \\
\hline & $\begin{array}{l}\text { is unethical and what is a } \\
\text { simply cultural difference. } \\
\text { However, the issues in this } \\
\text { category follow the criteria } \\
\text { of the study and follow the } \\
\text { legal standards in Canada.) }\end{array}$ & $\begin{array}{l}\text { "We could manufacture our whole } \\
\text { product overseas for a fraction of the } \\
\text { amount and we've been approached } \\
\text { about doing this as well." (cheaper labour } \\
\text { accepted in some cultures, but not in } \\
\text { Canada) } \\
\text { "We had to go back to the lawyers and } \\
\text { get the titles flipped (for the Japanese). } \\
\text { My title (in Japan) makes me equal." }\end{array}$ \\
\hline Bank Issues & $\begin{array}{l}\text { Any responses that made } \\
\text { mention to problems with the } \\
\text { bank behaving in a way that } \\
\text { discriminated or acted } \\
\text { unfairly/inconsistently, or } \\
\text { performed illegal } \\
\text { transactions. }\end{array}$ & $\begin{array}{l}\text { "I don't know if it's because I'm a } \\
\text { women or a man - I just think it is their } \\
\text { policy which happens to discriminate } \\
\text { against small business owners." } \\
\text { "She said she'd help us 'through', } \\
\text { because she was retiring and they (bank } \\
\text { management) had no way of finding } \\
\text { out."' }\end{array}$ \\
\hline Racism & $\begin{array}{l}\text { Any problems encountered } \\
\text { by the respondents due to } \\
\text { their visible ethnic origin and } \\
\text { race. }\end{array}$ & $\begin{array}{l}\text { "...it is probably my colour because the } \\
\text { Toronto-Dominion Bank, they know me } \\
\text { at that bank where I have my bank } \\
\text { manager. But bank managers change. I } \\
\text { always run into some difficulty to start } \\
\text { with initially with the new manager. I } \\
\text { went to the bank with that and they } \\
\text { thought I made a cheque, you know." } \\
\text { "I was the only person, a non-white and a } \\
\text { woman...and you find some of the } \\
\text { people were negative about it and treat } \\
\text { you differently." }\end{array}$ \\
\hline $\begin{array}{l}\text { Theft - } \\
\text { Copyright }\end{array}$ & $\begin{array}{l}\text { Any behaviour where the } \\
\text { respondents felt cheated, } \\
\text { mainly of their intellectual } \\
\text { property. }\end{array}$ & $\begin{array}{l}\text { "People can use my credentials to get } \\
\text { work and I don't like that." } \\
\text { "But it's extremely creative process and } \\
\text { what I find out is that what we find is big } \\
\text { companies that are well established, that } \\
\text { have a big staff, copy what we're doing." }\end{array}$ \\
\hline $\begin{array}{l}\text { Bureaucracy } \\
\text { (Government) }\end{array}$ & $\begin{array}{l}\text { Any difficulties with the } \\
\text { government of Canada or } \\
\text { international public sectors } \\
\text { that resulted in } \\
\text { discrimination or unjust }\end{array}$ & $\begin{array}{l}\text { "I can unequivocally say that the } \\
\text { experience has been painful because the } \\
\text { bureaucracy and the intricacy of the } \\
\text { Indian letters of credit." }\end{array}$ \\
\hline
\end{tabular}




\begin{tabular}{|c|c|c|}
\hline Ethical Issue & Description & Example \\
\hline & $\begin{array}{l}\text { behaviour toward a group } \\
\text { (i.e favouritism). }\end{array}$ & $\begin{array}{l}\text { "We found out that the Quebec } \\
\text { companies that were participating there } \\
\text { were subsidized and it only cost them } \\
\$ 500.00 \text {. My trade show activity for that } \\
\text { one trade show was about } \$ 20,000.00 \ldots . . \\
\text { we haven't had any favouritism." } \\
\text { "When Canadian forces have gathered } \\
\text { themselves and actually said, you know, } \\
\text { you (U.S) can't come in here and } \\
\text { dominate our theatrical screens, we're } \\
\text { not buying any of your processed wood } \\
\text { products. Although Americans say they } \\
\text { don't have protectionist policies, they, in } \\
\text { fact, have huge protectionist polices." } \\
\text { "What they're done is they're given } \\
\text { virtually all their money to a very small } \\
\text { number of large companies...and the } \\
\text { Houlle report concluded that this was a } \\
\text { terrible mistake (and actionable). So } \\
\text { what's happened is we've had Canadian } \\
\text { government funds going to support this } \\
\text { growth of three large companies." } \\
\text { (favouring large over small businesses) }\end{array}$ \\
\hline \begin{tabular}{|l} 
Dishonest \\
People/Brokers
\end{tabular} & $\begin{array}{l}\text { Any response that } \\
\text { demonstrated dishonest } \\
\text { behaviours or someone } \\
\text { agreeing to do something, } \\
\text { yet never fulfill, regardless } \\
\text { of the established } \\
\text { agreements. This also } \\
\text { includes not being } \\
\text { honest/open upfront when } \\
\text { agreeing to the terms. }\end{array}$ & $\begin{array}{l}\text { "When I first received my first broker, I } \\
\text { figured everything would be fine and } \\
\text { everything was okay until I realized there } \\
\text { are certain brokers that will only go into } \\
\text { the U.S.A. but not bring it (product) } \\
\text { back. And that was never expressed to } \\
\text { me until the product had to come back to } \\
\text { me and the hassles and frustrations that I } \\
\text { received were just phenomenal." } \\
\text { "I mean if they're going to take half your } \\
\text { money to sell your stuff you might as } \\
\text { well not bother....No I didn't know the } \\
\text { terms." } \\
\text { "They conveniently wiped the books." }\end{array}$ \\
\hline $\begin{array}{l}\text { Customs } \\
\text { Clearance }\end{array}$ & $\begin{array}{l}\text { Any behaviour that described } \\
\text { inconsistent actions by the } \\
\text { customs officers, due to } \\
\text { gender or no particular }\end{array}$ & $\begin{array}{l}\text { "Well one major problem of exporting } \\
\text { our services to the U.S.A. is hassles at } \\
\text { the border. Some get hassled. Some } \\
\text { don't. And I know that if it were my }\end{array}$ \\
\hline
\end{tabular}




\begin{tabular}{|c|c|c|}
\hline Ethical Issue & Description & Example \\
\hline & $\begin{array}{l}\text { reason. This also includes } \\
\text { officers accepting side } \\
\text { payments to let products } \\
\text { through. }\end{array}$ & $\begin{array}{l}\text { husband going down there to a meeting, I } \\
\text { know that he would get less questions." } \\
\text { "We find that - sometimes you talk to } \\
\text { one person they say this and another says } \\
\text { that. Sometimes they'll stop your order, } \\
\text { sometimes they won't. It's very } \\
\text { inconsistent and for no good reason." } \\
\text { "Now the first time we had no trouble at } \\
\text { all at the border and we paid our duties } \\
\text { on our goods and took them through. } \\
\text { But the second time we were stopped by } \\
\text { Immigration and were only allowed to } \\
\text { take samples and we had to pay extra to } \\
\text { pass all of our goods." }\end{array}$ \\
\hline $\begin{array}{l}\text { False } \\
\text { Advertising } \\
\text { (Pricing) }\end{array}$ & $\begin{array}{l}\text { Any response that } \\
\text { demonstrates unfair pricing } \\
\text { or advertising of a service } \\
\text { and actually offering } \\
\text { another. }\end{array}$ & $\begin{array}{l}\text { "Well, the Bank of Montreal advertises } \\
\text { themselves as a global bank and big } \\
\text { thinkers. They told us that we couldn't } \\
\text { put U.S. dollars on our promotional } \\
\text { material and that was one of their } \\
\text { requirements, although they don't have it } \\
\text { advertised as such." } \\
\text { "So my perception is that the federal } \\
\text { government uses the mission to finance } \\
\text { the cost of putting it on. That way they } \\
\text { get all the dignitaries paid for and all the } \\
\text { staff paid for and so and so forth. But } \\
\text { it's very expensive." }\end{array}$ \\
\hline Bribery & $\begin{array}{l}\text { Any response that } \\
\text { demonstrates behaviour of } \\
\text { paying out money for a } \\
\text { special or expedited service. }\end{array}$ & $\begin{array}{l}\text { "Somebody offered to fill in our PEMD } \\
\text { application. He works for the } \\
\text { government. What he did was illegal. } \\
\text { This guy said he would fill in our } \\
\text { documentation for } 15 \% \text { of what we } \\
\text { would get." }\end{array}$ \\
\hline Security Issues & $\begin{array}{l}\text { Responses regarding security } \\
\text { issues and behaviours that } \\
\text { are harmful to the } \\
\text { respondents. }\end{array}$ & $\begin{array}{l}\text { "And then Cambodia was not an easy } \\
\text { place to live from a political point of } \\
\text { view. There was some security issues." } \\
\text { "The only thing I'm a little bit concerned } \\
\text { about is my safety when I travel to some } \\
\text { places." }\end{array}$ \\
\hline No ethical issues & $\begin{array}{l}\text { Any interviews that did not } \\
\text { mention any ethical issues. }\end{array}$ & N/A \\
\hline
\end{tabular}


The following two tables show the breakdown and associated percentage for the export planners and active exporters. The associated percentages were calculated by dividing the number of ethical incidences by the total number of ethical issues mentioned. 'No ethical issues mentioned' were also included in the calculation. Table 11 shows the consolidated results for the entire sample, which is available later in the chapter.

Table 9 - Ethical Issues for Women Small Business Owners Who are Export Planners $(\mathrm{n}=14)$

\begin{tabular}{|c||l||c||c||}
\hline \hline Rank & \multicolumn{1}{|c|}{ Issue } & $\begin{array}{c}\text { Frequency } \\
\text { Mentioned }\end{array}$ & $\begin{array}{c}\text { Percentage (\%) of All Ethical } \\
\text { Issues Mentioned }\end{array}$ \\
\hline 1 & Gender and equity & 7 & 30.5 \\
\hline 2 & Cultural/business differences & 4 & 17.4 \\
\hline 3 & No ethical issues mentioned & 4 & 17.4 \\
\hline 5 & Bank Issues & 3 & 13.0 \\
\hline 6 & Racism & 2 & 8.8 \\
\hline 7 & Copyright theft & 1 & 4.3 \\
\hline 8 & Bureaucracy (Government) & 1 & 4.3 \\
\hline & Dishonest People (i.e. brokers) & 1 & 4.3 \\
\hline
\end{tabular}

Table 10 - Ethical Issues for Women Small Business Owners Who are Active Exporters $(\mathrm{n}=40)$

\begin{tabular}{|c|c|c|c|}
\hline Rank & Issue & $\begin{array}{l}\text { Frequency } \\
\text { Mentioned }\end{array}$ & $\begin{array}{l}\text { Percentage }(\%) \text { of All Ethical } \\
\text { Issues Mentioned }\end{array}$ \\
\hline 1 & Gender and equity & 12 & 18.5 \\
\hline 2 & Bureaucracy (Government) & 11 & 16.9 \\
\hline 3 & Dishonest People (i.e. brokers) & 10 & 15.4 \\
\hline 4 & No ethical issues mentioned & 7 & 10.8 \\
\hline 5 & Customs Clearance & 6 & 9.2 \\
\hline 6 & Cultural/business differences & 6 & 9.2 \\
\hline 7 & Bank Issues & 5 & 7.7 \\
\hline 8 & Security Issues & 4 & 6.2 \\
\hline 9 & False Advertising (Pricing) & 2 & 3.1 \\
\hline 10 & Copyright theft & 1 & 1.5 \\
\hline \multirow[t]{2}{*}{11} & Bribery & 1 & 1.5 \\
\hline & Total & 65 & 100 \\
\hline
\end{tabular}


It is also worth noting that the categories of ethical issues varied between the two groups. Export planners identified issues that fit into 8 specific categories, where the export planners outlined issues in 11 categories. The export planners identified racism as an ethical issue, while the active exporters did not. The other additional categories mentioned by the active exporters, but not the export planners include customs clearance, security issues, false advertising and bribery. This may be attributed to the fact that active exporters have much more experience in international trade and the foreign markets, and thus have encountered more difficulties in terms of clearing customs and the bureaucratic nature of some countries.

Table 11 below is a consolidation of Tables 9 and 10 to represent all the respondents of the study, plus the results from Mayo's 1991 study $(n=192)$. Although there is not an exact match on all the ethical categories, Mayo's results have been included to demonstrate similarities and differences that are discussed in the discussion section.

Table 11 - Ethical Issues for Women Small Business Owners ( $\mathrm{n}=54)$

\begin{tabular}{|c|c|c|c|c|}
\hline Rank & Issues & $\begin{array}{l}\text { Frequency } \\
\text { Mentioned } \\
\text { in this study } \\
\end{array}$ & $\begin{array}{c}\text { Percentage }(\%) \\
\text { of All Ethical } \\
\text { Issues Mentioned }\end{array}$ & $\begin{array}{c}\text { \% Mayo } \\
\text { (1991) }\end{array}$ \\
\hline 1 & Gender Issues & 19 & 21.6 & $-*$ \\
\hline 2 & Bureaucracy & 12 & 13.6 & 10.0 \\
\hline 3 & No ethical issues mentioned & 11 & 12.5 & 5.7 \\
\hline 4 & Dishonest People (i.e. brokers) & 11 & 12.5 & - \\
\hline 5 & Cultural/business differences & 10 & 11.4 & 6.4 \\
\hline 6 & Bank Issues & 8 & 9.1 & - \\
\hline 7 & Customs Clearance & 6 & 6.8 & 7.9 \\
\hline 8 & Security Issues & 4 & 4.5 & - \\
\hline 9 & Copyright theft & 2 & 2.3 & 4.3 \\
\hline 10 & Racism & 2 & 2.3 & - \\
\hline
\end{tabular}




\begin{tabular}{|c|c|c|c|c|}
\hline Rank & Issues & $\begin{array}{l}\text { Frequency } \\
\text { Mentioned } \\
\text { in this study }\end{array}$ & $\begin{array}{c}\text { Percentage (\%) } \\
\text { of All Ethical } \\
\text { Issues Mentioned }\end{array}$ & $\begin{array}{c}\text { \% Mayo } \\
\text { (1991) }\end{array}$ \\
\hline 11 & False Advertising (Pricing) & 2 & 2.3 & 2.9 \\
\hline 12 & Bribery & 1 & 1.1 & 33.6 \\
\hline 13 & Immoral entertainment & - & - & 2.1 \\
\hline 14 & Transfer of funds & - & - & 6.4 \\
\hline 15 & Product use & - & - & 0.7 \\
\hline \multirow[t]{2}{*}{16} & Miscellaneous & - & - & 20.0 \\
\hline & Total & 88 & 100 & 100 \\
\hline
\end{tabular}

$*=$ not encountered in the respective study

Vyakarnam's (1997) model was also tested in this study, although with less success than Mayo's model. Each interview was analyzed and examined for examples of the following dilemmas abiding by the guidelines used by Vyakarnam et al. (1997).

- Conflict of Interest

- Social Responsibility to Stakeholders

- Level of Openness

- Personality Traits

However, the ethical issues encountered in this study did fit well into those categories proposed by Vyakarnam et al. (1997), thus contributing little to the findings. Only one respondent discussed an instance where they felt that entrepreneurial activity was unethical, because of the level of openness. That is, does one recommend a competitor because they are can perform better, and the entrepreneur knows this to be true? It appears that this model would produce more valuable results when the dilemma is actually 'created' by the entrepreneur. That is, when they are the ones deciding what the outcome will be. For example, when a small business owner is faced with firing an employee, they are the ones who decide if they will act in an ethically or unethically way. 
On the other hand, when an entrepreneur is faced with gender or racism issues, they are not the ones imposing the challenges onto themselves. It is of the opinion the author of this thesis that Vyakarnam et al.'s (1997) work would generate more valuable findings if the question of ethical dilemmas were asked directly to the respondents, because the question would specifically ask what ethical decisions they have had to make. However, this may also lead to underreporting of ethical issues, because respondents may hesitate to admit that they were encountered with an ethical decision (i.e. firing an employee and knowing that he will not be able to support his family) and they ultimately made a choice that was not the most ethical. Another possibility may be overeporting, where respondents describe instances where they have acted in an ethical fashion, but that may not be the case because of the potential tendency to want to appear ethical. The best method to obtain results may be to observe daily business operations, although this may require an extended period of observation.

Therefore, the results from the Vyakarnam et al. (1997) model do not help to clarify what the actually issues that woman small business owners faced in this study. The categories discussed earlier, which were influenced by Mayo et al.'s (1991) original work, prove to shed more light on what the specific issues are, and what a small business owner faces when engaging in business activities both nationally and internationally. However, the ethical decision-making filters proposed by Vyakarnam et al. (1997) are more useful and discussed in the following sections. 


\subsection{Results Associated With Research Question 3}

- How, if at all, do entrepreneurs attempt to resolve the ethical issues discovered in questions 1 and 2 ?

When asked about resolving the challenges/ethical issues listed above in the previous section, the respondents did identify that they do attempt to resolve the issues. The most common approaches taken to resolve the ethical issues mentioned by the small business respondents were:

- Research markets, customers, products, country laws and regulations

- Keep contacts fresh and follow-up up any potential leads

- Hire men to help

- Team up with large businesses

- Cross-cultural training (i.e. language classes)

- Ignore the problem and/or do nothing (i.e. "it will go away with time.")

The list mentioned above were the most common responses given by the women (95 percent). A large proportion (48 percent) directly or indirectly answered, 'Ignore the problem and/or do nothing'. This again may be attributed to the fact that the women may not realize that there is actually a problem that could ultimately impede business operations. Those that did have strategies, such as research markets or hire a man, may have recognized that the cultural differences needed to be addressed, and action required in order to avoid further development of such problems. Although the women did not identify certain problems as unethical, they did take measures to mitigate the repetition of certain issues. However, again it was found that none of the strategies listed above were 
included in a formal code or institutionalized documentation. This is to be expected and aligns well with the Morris et al. (2002) model - Evolution in the ethical reference point as ventures grow (see Section 2.2.1). All the respondents in this study fit in Level 1 of the diagram and there is no indication of any formal ethics structure at all, so these results are to be expected.

Vyakarnam et al. (1997) also provided a web of filters that small businesses use to resolve ethical dilemmas (see Section 2.2.2). Again, although the respondents were not directly asked to comment on ethical issues, their methods of resolutions fit with many of the filters proposed by Vyakarnam et al. (1997). For instance, the respondents in this study found quality of relationships to be an important factor and thus considered its impact on decision-making. Other filters included; culture, personality, legal and intuition. The last three appeared to be most prominent in driving business decisions. The law, for example, especially in international trade, has a large impact on what can and cannot be done. In addition, being that formal behavioural structures or codes are not in place, the respondents depend greatly on their personality and intuition to make and guide what they will do. Again, the perception here may be that the women were not aware that they were actually following such models, but depended more on experience and what they felt to be right.

\subsection{Results Associated With Research Question 4}

- Are there any indications of managerial strategies (i.e. legal compliance and/or organizational integrity) reflected in the actions that entrepreneurs take to mitigate and/or resolve ethical issues? 
The analysis of the interviews showed indications of the women entrepreneurs using both Paine's legal compliance strategy and the organizational integrity strategy when conducting business nationally and internationally. To summarize, the legal compliance strategy is adherence to the letter of the law and the desire to avoid public outrage, loss of public trust and a tarnished image. On the other hand, the organizational integrity strategy is adherence to the spirit of the law, as it fully acknowledges the laws importance and the aim is to achieve the right conduct in general. The women respondents spoke candidly of the importance of following the law and regulations (in Canada and abroad), specifically emphasizing greater importance of compliance in international trade activities. The integrity strategy was used not only when dealing with customers, but also in employee relationships, showing consistency of behaviour across various types of relationships. The following chart outlines some of the responses given by the small business owners that demonstrate these managerial strategies.

Table 12 - Evidence of Managerial Strategies demonstrated by Respondents

\begin{tabular}{||l||l||}
\hline \multicolumn{1}{|c||}{ Type of Strategy } & \multicolumn{1}{c|}{ Actions within Strategy } \\
\hline \hline Organizational Integrity & "Do everything you possibly have to do to move mountains \\
Strategy & $\begin{array}{l}\text { "It's very important to me that the people in my firm are } \\
\text { happy in their work... and keeping my domestic clients } \\
\text { happy." } \\
\text { "I'm especially honest and I hate to tell people that they } \\
\text { need something that don't need." } \\
\text { "We pride ourselves on customer service and we try to have } \\
\text { a minimum one hour turnaround on any call so whether it's } \\
\text { a support call or a sales call or accounting, it doesn't really } \\
\text { matter." }\end{array}$ \\
\hline \hline
\end{tabular}




\begin{tabular}{|l|l||}
\hline \hline Type of Strategy & \multicolumn{1}{|c|}{ Actions within Strategy } \\
\hline "We have to help each other every way that we can because \\
there's a big enough market for everybody." \\
"We take care of the people and we want to know if they're \\
doing good and for us its part of them being happy at work \\
and you enjoying having them as your employees." \\
"Keeping the group happy. That can be a big one because \\
if your reps aren't happy, then you're screwed." \\
"So it was more of the excellent customer service really, \\
always being available for him. Walking him through, e- \\
mailing him and making sure that his level of satisfaction \\
was high."
\end{tabular}

Although the analysis demonstrated that these strategies were in fact present, the respondents did not appear to use them intentionally to resolve any specific ethical issues. As a result of complying with the law and showing organizational integrity, potential ethical issues were perhaps avoided, but that may not have been the main objective of following such approaches. Small businesses have many daily barriers to overcome each day and one of these main concerns is to avoid being involved in activities that could cause legal problems or misunderstandings, especially when conducting business overseas. Many respondents, when asked to provide advice, recommended other small business owners who export to do research prior to entering certain markets, as not to 
become involved in difficult and often costly situations, thus showing conscious knowledge of the benefits of abiding by the law.

However, these strategies may not be the number one organizational priority because they have not been implemented into formal systems, mission statements or codes of ethics. As previously stated, the majority of small businesses do not depend on institutionalized systems that dictate daily behaviours and decisions, because of the nature of small firms. Rather, decisions are made based on relationships and almost always are designed to fulfill short-term goals. The presence of these strategies in daily business operations may also give more insight on the personality traits of the entrepreneurs, as these strategies come directly from them making decisions and not because a code dictates it. In addition, as also demonstrated by Joyner et al. (2002), this finding reinforces that these two strategies do not only apply to large business as originally proposed by Paine. 


\section{Discussion of Findings}

This section provides a discussion of the results presented above, in the context of the theoretical literature and empirical findings surrounding the topic of small business ethics and international trade. This thesis addressed the need for further research into this topic, incorporating the work of past researchers and demonstrating its generalizability, while attempting to advance the knowledge of such an infant body of literature. The results of this thesis indicate that there are several ethical issues that confront women small business owners who engage in international trade, it also shows that they attempt to resolve these issues with the use of managerial strategies. It was also attempted to identify mention of formal codes of ethics, but there was no evidence of this.

The results show that there are several ethical issues that are present in the small business environment of those firms that engage in exporting activities. The women respondents in this study outlined 12 distinct categories; the most frequently cited ethical issue mentioned by $21.6 \%$ of all respondents was gender and equity. This issue may have been mentioned most because it was the only specific question regarding any of the ethical categories that was asked directly to the respondents. Nevertheless, while gender was a key ethical issue it was not the only issue. Without being asked directly, respondents mentioned 11 other types of ethical issues (excludes 'no ethical issues mentioned'). Although it can be said that the perception is that women believe that they are being treated differently in comparison to male counterparts at the national and international levels, many other issues were outlined that have nothing to do with gender. Many women thought that being a small business was the factor that caused them to be treated differently by banks, governments or customs agents, for instance. 
Other frequently mentioned categories included bureaucracy (13.6\%) and dishonest people $(12.5 \%)$. It appears that many respondents had difficulties dealing with local and outside government agencies. In addition, the women exporters mentioned incidences where they were promised something and the service was never completed or the terms of agreement were not made clear from the start. The lowest scoring ethical issue was bribery $(1.1 \%)$ and false advertising, racism and copyright theft each made up $2.3 \%$ of the responses. This may be a result of the increased controls and consequences of such dilemmas by many countries. For example, the penalties associated with copyright theft have increased tremendously over the past decade.

However, it was discovered that not all the categories proposed by Mayo (1991) were useful topics to explore in this study. Some of the issues mentioned in the 1991 study were not an issue for those respondents in this present study. In addition, new issues not captured by Mayo's study are outlined here.

As explained in the Literature Review, Mayo identified five main issues that posed the most difficulty for those small businesses that are involved in international trade. His 192 participants described these as the most prevalent issues; bribery, government interference, customs clearance, transfer of funds and cultural/business differences. It can be seen from the table above that the five main issues for this study's total respondent group are gender issues, bureaucracy, dishonest people and cultural/business differences. It is evident that there is a difference between the two studies, especially with respect to 
gender. There may be many reasons to explain this variance aside from the fact the each person's interpretation and experience of ethics can vary greatly. Firstly, the concentration on gender was emphasized more in this study, because it segmented the respondents, where the Mayo study did not. In addition, there were no indications of transfer of funds issues in this current study, whereas in the Mayo study, it represented a large dilemma. This may be attributed to the fact that during the years between the two studies (Mayo in 1991, Orser et al. in 1999) business people have taken greater measures to avoid such mishaps and losses. In addition, government agencies and organizations, such as Export Development Canada, have more services (i.e. insurance options) available to small businesses to help them to receive payments and take the funds out of international countries more easily/safely. Cultural and business issues identified reflect that when working with people of different nations, attitudes and behaviours may vary and because it is sometimes difficult to understand why certain behaviours are acceptable for some and not others. This is an issue that will probably never disappear. It is possible to educate oneself on cross-cultural differences, but it is not always easy to accept the daily practices of others that are of another culture. Lastly, Mayo outlined that bribery was the largest issue (33.6\%) encountered by small business exporters. In this study, very few examples $(1.1 \%)$ were found that showed such behaviour, again maybe due to the heightened awareness of bribery and its associated major consequences that have been extremely prevalent in the media and business schools. However, one is still left to wonder what happened to all the bribery. Mayo's (1991) respondent group was American and the United States exports to various countries, especially to its southern neighbours. This study, on the other hand, looked at a Canadian respondent group which 
conducted the majority of its exporting activities to the United States, where bribery is not tolerated. Although it cannot be confirmed in this study, it can be speculated that the difference in findings is perhaps attributed to the exporting partners accepted business practices.

Another interesting finding is that 11 out of the 54 respondents did not mention any ethical problems, yet 88 different scenarios were expressed by the remaining 43 participants (average 2 issues per respondent). Those who did not express any challenges perhaps did not recognize the issues as something that could ultimately impede them from being successful. The inability to distinguish business problems can cause several obstacles, because it may prevent the manger from utilizing the appropriate and correct solutions.

Additional findings show that women small business owners depend mostly on their legal responsibilities, their personality traits and intuition, and on the quality of relationships for solving ethical dilemmas. Formal methods or structures are not in place that dictate how challenges and dilemmas should be solved, which is to be expected in the small business environment. After all, the entrepreneur is often the entire business structure for such small businesses. Also worth noting is the appearance of the continual tension between business ethics and competitive advantage. The decisions an entrepreneur must make often cause a struggle between acting in a fair and ethical way, while attempting to stay competitive in a sometimes aggressive business environment. 
When looking for specific managerial strategies two tested strategies were reported most frequently. Women owners employ both the organizational integrity strategy and the legal compliance strategy. There are indications of both these daily behaviours of these respondents, when working nationally and internationally. Once more, they have not explicitly written out codes to incorporate these strategies, but they appear to communicate their intentions through daily actions.

In order to appreciate the impact of the ethical problems of small businesses and their associated members, it is important to consider the structure, limited supply of resources and orientation of the firm that influences the ability of the entrepreneur to handle such issues. Longenecker et al. (1989) suggest that in comparison to large firms, small businesses maybe more profit-oriented and more tolerant of unethical practices when financial well-being is on the line (Longenecker et al., 1989). Therefore, small businesses and managers need to recognize the likelihood of facing the key ethical issues that have been identified in this study. In addition, given that small businesses do not often have the necessary personal (i.e. ethics officers) to help manage/mitigate ethical problems, it can be very difficult to deal with foreign governments and ethical challenges that may interfere with successful foreign trade. 


\section{$7 \quad$ Strengths \& Limitations of the Research}

This chapter examines the strengths and limitations of this thesis. Business ethics as it relates to large businesses has a reasonably well-defined literature, whereas the literature on small business ethics is essentially in its infant stages. Very few empirical studies can be found in this area. The research conducted here will help uncover the key ethical issues women entrepreneurs are faced with when engaging in international trade. As one of the first Canadian studies in this area, the results obtained in this study will add to both the literature on small business ethics, in addition to the area of Canadian small business exporting.

In addition, a wide range of sectors is represented in the sample and it has been noted that sector differences can be highly significant in small firm research (Curran and Blackburn, $1994 ;$ p. 55). This study is exploratory in nature and the variety in sectors may help in identifying any similarities in small firms across the sectors in further studies.

This research is also based on a well-tested questionnaire used by Orser, Riding and Townsend. A sample size this large would be difficult for a Master's candidate to obtain due to the additional resources required. By re-analyzing data originally collected for another purpose, this research has both strengths and weaknesses. The instrument does not explicitly make reference to ethics resulting again in both strengths and weaknesses in the research. As mentioned earlier, this method decreases the likelihood of participants providing socially desirable responses and over reporting ethical issues. Spence and Lozano (2000) agree with this approach and suggest, “...business ethics 
researchers would be well advised to take care in the terminology they adopt when attempting to access information about ethics issues in small firms" (Spence and Lozano, $2000 ;$ p.52). The subjects in the study were aware that all the information in their interview would be analyzed to give a multi-dimensional picture of the small business exporting. Therefore, ethical issues were within the boundaries of the data collection even though they were never specifically identified as such to the participants.

Despite the strengths, there exist some limitations worth noting. The sample is not necessarily representative of all businesses owned by firms, as it is a convenience sample and may reflect non-response bias. It includes only women exporters and export planners, which is not representative of all women business owners. However, since the participants are not directly probed to give examples of ethical issues, this may result in underreporting, as some ethical issues may in fact be present or have occurred but were not mentioned. The age of the dataset is worth also commenting upon. Since the original 1998 study, many visible events have occurred regarding the unethical behaviour of many businesses, specifically large multinationals. It is difficult to speculate on how these mishaps by businesses may have impacted the ethical issues encountered by small business owners, or if these incidences may affect the perception these women entrepreneurs have of business ethics. Therefore, the research findings that will be extracted from this study must be considered exploratory in nature and serve as a starting point for ethics research in this field. 


\section{Conclusions}

This thesis can be placed in a body of literature that is new and still requires attention by the research community. There were, and continue to be, gaps that this thesis attempted to fill. The concrete ethical issues of the small businesses were not well developed and the need to include a global element was important in today's economy and business environment. Previous studies found it difficult to truly know the behaviour and perceptions of the respondents due to the delicate field of business ethics. This study took these factors into consideration and obtained some interesting findings.

The findings of this study show that there are 12 distinctive types or categories (includes no issues mentioned) of ethical issues encountered and mentioned by women exporters (specifically 8 for export planners, 11 for active exporters). The identification of these categories is vital in the continuation of business ethics research. Nevertheless, further research is needed to verify the existence of these categories. Based on these findings, strategies to help small business owners identify and resolve ethical issues can be formed more effectively. In addition, it has been shown that small businesses do in fact depend on the owner/manager to make the decisions and to resolve issues around ethics. This study reinforces earlier studies showing that small businesses do not have structured codes in place to deal with ethical issues, probably because the everyday demands of small firms are too significant. In conjunction with the results extracted from the Joyner et al. (2002) study, the women owners showed that they were consistently following the legal requirements set by the law and also that they were highly concerned with keeping 
their customer, employees and suppliers continuously happy. The quality of relationships with these groups was found to be an important factor in decision-making.

This research can serve as a stepping-stone for future studies to discover the explanations for many of the findings provided. As this is an exploratory study, the first of its kind in Canada, it is necessary that these findings be tested with larger sample groups that also include the input of men. In addition, the ethical issues (in Tables 9 and 10) could aid policy makers focus their attention on programs that address the issues of both export planners and active exporters, in an effort to better prepare entrepreneurs and minimize unethical occurrences.

\subsection{Implications}

This present study provides a list of challenges for small business mangers involved in exporting. It has been suggested that small business professionals begin to incorporate ethics into decision-making by first identifying the ethical problems that might develop between the firm and its relevant stakeholders. Therefore, it is recommended that entrepreneurs consider the ethical qualities of the various means to resolve each ethical dilemma that has been identified. Ethical solutions are those business decisions “...that lead to a net positive value to the affected stakeholders" (Chittipeddi, 1987). Even though each business decision may represent a net positive value, the outcome on each stakeholder will vary across solutions. Often the final solution chosen in a small business to resolve an ethical issue often the values and personality of the entrepreneur. 
As the firms grows and managers develop administrative policies surrounding the problems associated with various stakeholders important to the firms, a code of ethics is constructed. Codes constructed in this manner provide managers with realistic definitions of ethical responsibilities and encourage them to include ethical standards in their decision-making.

\subsection{Directions for Future Research}

The following are a few suggestions for future research in the area of small business ethics and exporting. To further build on this study, it is suggested that men be included in the sample and compare if the results are similar, again without directly asking ethical questions. As well, evidence of changes in the findings as a result of the passage of time could be explored. The rationale behind including men is to attempt to uncover if the ethical issues are gender related and perhaps attributed to the gender socialization of women.

Another approach could be to construct a new survey and explicitly ask both male and female small business exporters to comment on the ethical issues encountered and compare the frequency of the responses. That is, are there more issues because the topic of business ethics was made explicit or did the issues remain roughly the same? The methodology suggested to gather the information is to observe the respondents in the small business environment and to note the ethical issues and resolution approaches, while including the perceptions of the entrepreneurs. 


\section{Bibliography}

Andrews, Kenneth R. (1989) "Ethics in Practice". Harvard Business Review September October, p99-104.

Bagchi-Sen, Sharmistha (1999) "The Small and Medium Sized Exporters' Problems: An Empirical Analysis of Canadian Manufacturers." Regional Studies, Vol. 33 Issue $3, \mathrm{p} 231-245$.

Berenbeim, Ronald E. (1987) “The Corporate Ethics Test”. Business and Society Review, Fall Issue, p22-25.

Brooks, Leonard J., (1989) "Corporate Ethical Performance: Trends, Forecasts, and Outlooks." Journal of Business Ethics, Issue 1, p31-39.

Brooks, Leonard J. (1997) "Business Ethics in Canada: Distinctiveness and Directions”. Journal of Business Ethics, Vol. 16, p591-604.

Brown, Daniel J., and King, Jonathon B. (1982) Small Business Ethics: Influences and Perceptions. Journal of Small Business Management, p11-18.

Business Register of Statistics Canada (2005), Key Small Business Statistics. Industry Canada January:

http://strategis.ic.gc.ca/epic/internet/insbrprppe.nsf/en/rd00998e.html

Cadbury, Adrian (1987) "Ethical managers make their own rules." Harvard Business Review, Vol. 65 Issue 5, p69-73.

Carland, J. W., Hoy, F., Boulton, W. R., Carland, J. C. (1984) "Differentiating Entrepreneurs from Small Business Owners: A Conceptualization." Academy of Management Review, Apr84, Issue 2, p354-359.

Carroll, A.B. (1991) "The Pyramid of Corporate Social Responsibility: Toward the Moral Management of Organizational Stakeholders". Business Horizons, Vol. 34, Issue 4, p39-48.

Chittipeddi, Kumar (1978), "Integrated Ethics Into Organizational Decision Making," presented at the 1987 World Conference of the International Council for Small Business (June 11, 1987), Vancouver, B.C., Canada.

Chrisman, J. J., Fry, F. L. (1982) "Public Versus Business Expectations: Two Views On Social Responsibility For Small Business." Journal of Small Business Management, Vol. 20 Issue 1, p19-26

CIBC Small Business (2004) "Women Entrepreneurs: Leading the Charge". Resource Centre: Small Business Economic Reports and News: $\mathrm{http}: / / \mathrm{www} . c i b c . c o m / \mathrm{ca} / \mathrm{pdf} /$ women-entrepreneurs-en.pdf 
Conill, J. (2000) "El perfil Etico de la cultura empresarial en la Comunidad Valenciana. ETNOR - Economia 3.

Dawson, S., Breen, J., Satyen, L. (2002) "The Ethical Outlook of Micro Business Operators. " Journal of Small Business Management, Vol. 40 Issue 4, p302-313.

Donaldson, Thomas and Werhane, Patricia H. (1993) Ethical Issues in Business: A Philosophical Approach. Englewood Cliffs, N.J.: Prentice Hall.

Dunfee, T., Bowie, N., Hennessy, J., Nelson, K. and Robertson, D. (1991) "Firm Size and Employees' Attitudes About Ethics: Some Preliminary Empirical Evidence”. In Harvey B., Van Luijk, H. and Corbetta, G. (eds), Market Morality and Company Size: 103-118. London: Kluwer.

Ede, Fred O.; Panigrahi, Bhagaban; Stuart, Jon; Calcich, Stephen. (2000) "Ethics in Small Minority Businesses.” Journal of Business Ethics, Vol. 26 Issue 2, p133146.

Enz, C.A., Dollinger, Marc J., Daily, Catherine M., (1990) “The Value Orientations of Minority and Non-Minority Small Business Owners". Entrepreneurship Theory and Practice, Fall Issue, p23-35.

Epstein, Edwin M. (1987) "The Corporate Social Policy Process: Beyond Ethics, Corporate Social Responsibility and Corporate Social Responsiveness". California Management Review, Spring Issue, p99-115.

Evans, Richard (1991) "Business Ethics and Changes in Society". Journal of business Ethics, November, p871-876.

Friedman, Milton (1970) "The Social Responsibility of business Is to Increase Its Profits". New York Times Magazine, 13 September 1970. Reprinted in Business Ethics in Canada, Third Edition,edited by Deborah C. Poff and Wilfrid J. Waluchow. Toronto, Ontario; Prentice Hall Canada, 1999, p43-47.

Fritzche, David J.; Becker, Helmut (1984), "Linking Management Behavior in Ethical Philosophy - An Investigation." Academy of Management Journal, Vol.27, p.166175.

Goddard, Robert W. (1988) “Are You an Ethical Manger?” Personnel Journal, March Issue, p.38-47.

Insights, Statistics Canada (1999) http://www.statcan.ca/english/freepub/61F0019XIE/61F0019XIE2000001.pdf

Hartman, Laura (2002) Perspectives in Business Ethics: Third Edition. McGraw-Hill Irwin, Boston. 
Hector, Gary (1989) “Cute Tricks on the Bottom Line”. Fortune, April 24, p193-200.

Hornsby, J., Kuratko, D. F. (1994) “The ethical perceptions of small business owners: A factor analysis study." Journal of Small Business Management, Vol. 32 Issue 4, p9-16.

Huberman - Arnold, Diane; Arnold, Keith (2003) "Global Business Ethics and Codes". Business and Professional Ethics Journal, Vol.22, No.2, p73-88.

Humphreys, Neil, Robin D.P., Reidenbach, R.E., Moak D.L. (1993) "The Ethical Decision Making Process of Small Business Owner/Managers and Their Customers". Journal of Small Business Management, Vol. 31, Issue 3, p9-22.

Industry Canada (2002) Government of Canada, Small and Medium-Sized Enterprises (SME) Financing in Canada, 2002 available at http://strategis.gc.ca/fdi. The report is based in part on Statistics Canada's Survey on financing of Small and Medium Enterprises, 2000.

Jones-Evans, D. (1993) "Paths of Enterprise: The Future of the Small Business (Social Analysis)." Service Industries Journal, Vol. 13 Issue 1, p141-143.

Joyner, B. E., Payne, D., Raiborn, C. A. (2002) "Building Values, Business Ethics and Corporate Social Responsibility Into The Developing Organization." Journal of Developmental Entrepreneurship, Vol. 7 Issue 1, p113-131.

Kirrane, Dianne E. (1990) "Managing Values: A Systematic Approach to Business Ethics." Training \& Development Journal, Vol. 44 Issue 11, p52-59.

Kohlberg, Lawrence (1964) "Development of Moral Character and moral Ideology". Review of Child Development Research, eds. Hoffman H. and Hoffman L., Vol. 1 (New York: Russell Sage Foundation).

Labbé, P. (1994) "SMEs in the Global Economy". Canadian Business Review, Spring Issue, p. 22-24.

Longenecker, J. G., McKinney, J. A., Moore, C. W. (1989) "Ethics In Small Business." Journal of Small Business Management, Vol. 27 Issue 1, p27-31.

Longenecker, J. G., Schoen, J. E. (1975) "The Essence Of Entrepreneurship." Journal of Small Business Management, Vol. 13 Issue 3, p26-32.

Mayo, Michael A.; Marks, Lawrence J.; Ryans Jr., John K. (1990) “Ethical Problems Encountered in International Marketing: An Empirical Investigation." International Marketing Review, Vol. 8 Issue 3, p61-75.

Mayo, Michael A. (1991) "Ethical Problems Encountered by U.S. Small Businesses in 
International Marketing”. Journal of Small Business Management, Vol.29, Issue 2, p51-59.

McMahon, T.F. (1999) "A Brief History of American Business Ethics". In Frederick, R.E. A Companion to Business Ethics: p342-352. Malden, MA/ Oxford, UK: Blackwell Publishers.

McDonald, Gael M., and Zepp, Raymond A. (1989) "Business Ethics: Practical Proposals".Journal of Management Development, Winter Issue, p55-67.

McRea, B. (1998). Literature Review on Women in International Trade, Ottawa: conducted on behalf of the Department of Foreign Affairs and International Trade and Industry Canada.

Morris, Michael H.; Schindehutte, Minet; Walton, John; Allen, Jeffrey (2002) "The Ethical Context of Entrepreneurship: Proposing and Testing a Developmental Framework." Journal of Business Ethics, Vol. 40 Issue 4, p331-361.

OECD Conference (2002) on Women Entrepreneurs in SMEs: Realising the Benefits of Globalisation and the Knowledge-based Economy, Paris, 29 November - 1 December, 2000.

Orser, Barbara, Riding, Allen, Townsend, JoAnna (1999) "Beyond Borders - Canadian Businesswomen in International Trade" Department of Foreign Affairs and Trade presented on Women's Day, March 8, 1999.

Orser, Barbara, Riding, Allen, Townsend, JoAnna (2004) "Exporting as a Means of Growth for Women-owned Canadian SMEs". Journal of Small Business and Entrepreneurship, Vol. 17, Issue 3, p1-22.

Paine, Lynn, S. (1994) "Managing For Organizational Integrity". Harvard Business Review, p106-117.

Paine, Lynn S. (1996) "Venturing beyond Compliance". The Evolving Role of Ethics in Business, Report No. 1141-96-ch, p13-16 (New York: The Conference Board, Inc.)

Poff, Deborah C. ed., (2005) Business Ethics in Canada Fourth Edition. Pearson Prentice Hall, Toronto, Canada.

Pope, Ralph A. (2002) "Why Small Firms Export: Another Look..” Journal of Small Business Management Vol. 40 Issue 1, p17-26.

Quinn, J.J. (1997) "Personal ethics and business ethics: The ethical attitudes of owner/managers of small business." Journal of Business Ethics, Vol. 16 Issue 2, p119-128. 
Robertson, D. (1993) "Empiricism in business ethics: Suggested Research Directions". Journal of Business Ethics, Vol. 12, p585-599.

Robin, Donald; Giallourakis, Michael; David, Fred R.; Moritz, Thomas E. (1989) “A Different Look at Codes of Ethics.” Business Horizons, Vol. 32 Issue 1, p66-73.

Ryan, L. (1991) "The Ethics of Social Responsibility of United States Small Business: The 'Overlooked' Research Agenda”. Van Luijk, H. and Corbetta, G. (eds), Market Morality and Company Size: p89-102. London: Kluwer.

Small Business Research Centre (1997), Indictors of Success and Failure in young Micro Firms. A Report to SOLOTEC, Kingston Business School: Kingston University, March.

Smith, P.L. and Oakley, E.F. III. (1994)" A Study of the Ethical Values of Metropolitan and Nonmetropolitan Small Business Owners". Journal of Small Business Management, Vol. 32, Issue 4, p17-27.

Solymossy, Emeric; Masters, John K. (2002) "Ethics Through an Entrepreneurial Lens: Theory and Observation.” Journal of Business Ethics, Vol. 38 Issue 3, p227-241.

Spence, L. J. (1999) "Does size matter? The state of the art in small business ethics." Business Ethics: A European Review, Vol. 8 Issue 3, p163-174.

Spence, L. J., Lozano, J. F. (2000) "Communicating about Ethics with Small Firms: Experiences from the U.K. and Spain." Journal of Business Ethics, Vol. 27 Issue $1 / 2, \mathrm{p} 43-53$.

Statistics Canada, Canadian Exporter Registry, July 2004:

http://strategis.ic.gc.ca/epic/internet/insbrp-rppe.nsf/en/rd01013e.html

Stodder, J. (1998) “Goodwill Hunting”. Entrepreneur, July, p118-121.

Taper, Steven (1995). "From Main Street to Mexico City," Cross Currents, Federal Reserve Bank of Richmond, 22.

Thompson, J. K.; Smith, H. L. (1991) "Social responsibility and small business: Suggestions for research.” Journal of Small Business Management, Vol. 29 Issue $1, \mathrm{p} 30-44$.

Vitell, Scott J.; Dickerson, Erin Baca; Festervand, Troy A. (2000) "Ethical Problems, Conflicts and Beliefs of Small Business Professionals." Journal of Business Ethics, Vol. 28 Issue 1, p15-24. 
Von der Embse, Thomas J.; Wagley, Robert A. (1988), "Managerial Ethics: Hard Decisions on Soft Criteria." SAM Advanced Management Journal, Vol. 53 Issue 1, p4-9.

Vyakarnam, S., Bailey, A., Myers, A., Burnett, D. (1997) "Towards an Understanding of Ethical Behaviour in Small Firms." Journal of Business Ethics, Vol. 16 Issue 15, p1625-1636.

Welsh, D.H.B., and Birch, N.J. (1997) "The Ethical Orientation of U.S. Small Business Decision Makers: A Preliminary Study”. Journal of Small Business Strategy, Vol. 2, p41-51.

Werner, Simcha B. (1992) "The Movement for Reforming American Business Ethics: A Twenty-Year Perspective". Journal of Business Ethics, Vol. 11, January Issue, p61-70.

Wilson, E. (1980) "Social Responsibility of Business: What Are the Small Business Perspectives?” Journal of Small Business Management, pp.17-24.

Wood, D.J. (1991) “Towards Improving Corporate Social Performance”. Business Horizons, Vol. 34, Issue 4, p66-73. 


\title{
Appendix A - Longenecker et al. (1989) Questionnaire
}

\author{
LONGENECKER, MCKINNEY, AND MOORE \\ ETHICS IN SMALL BUSINESS \\ SUAVEY ITEMS
}

Item

Survey ltem

1. An executive earning $\$ 50,000$ a year padded his/her expense account by about $\$ 1,500$.

2. In order to increase profits, a general manager used a production process which exceeded legal limits for environmental pollution.

3. Because of pressure from his/her brokerage firm, a stockbroker recommended a type of bond which heishe did not cansider a good investment.

4. A small business received one-fourth of its gross revenue in the form of cash. The owner reported only one-half of the cash receipts for income tax purposes.

5. A company paid a $\$ 350,000$ "consulting" fee to an official of a foreign country. In return, the official promised assistance in obtaining a contract which should produce a $\$ 10$ million profit for the contracting company.

6. A company president found that a competitor had made an important sclentific discovery which would sharply reduce the profits of his own company. He then hired a key employee of the competitor in an attempt to learn the details of the discovery.

7. A highway building contractor deplored the chaotic bidding situation and cut-throat competition. $\mathrm{He}$, therefore, reached an understanding with other major contractors to permit bidding which would provide a reasonable profit.

8. A company president recognized that sending expensive Christmas gifts to purchasing agents might compromise their positions. However, he continued the policy since it was common practice and changing it might result in loss of business.

9. A corporate director learned that his company intended to announce a stock split and increase its dividend. On the basis of this information, he bought additional shares and sold them at a gain following the announcement.

10. A corporate executive promoted a loyal friend and competent manager to the position of divisional vice president in preference to a better-qualified manager with whom helshe had no close ties.

11. An engineer discovered what he perceived to be a product design flaw which constituted a salety hazard. The company declined to correct the flaw. The enginesr decided to keep quiet, father than taking his complaint outside the company.

12. A comptroller selected a legal method of financial reporting which concealed some embarrassing financial facts which would atherwise have become public knowledge.

13. An employer received applications for a supervisor's position from two equally qualified applicants but hired the male applicant because he thought some employees might resent being supervised by a temale.

14. As part of the marketing strategy for a product, the producer changed its color and marketed it as "new and improved" even though its other characteristics were unchanged.

15. A cigarelte manufacturer launched a publicity campaign challenging new evidence from the Surgeon General's office that clgarette smoking is harmful to the smoker's health.

16. An owner of a small firm obtained a free copy of copyrighted computer software program from a business friend rather than spending $\$ 500$ to obtain his/her own program from the soltware dealer.

R. Coscarella 


\section{Appendix B - Telephone Qualitative Interview}

\section{Section 1: Decision to Export and Context}

I would like to begin by asking you to reflect back to before you first considered exporting.

1. At that time, what were your main goals for the business?

- PROMPTIF NECESSARY:

* By what measure would you consider your business a "success".

* What were the important issues and challenges that faced your firm?

2. What prompted your decision to export?

- PROMPTIF NECESSARY:

* Were there one or more critical factors or events that prompted your decision to export?

* How did you know the time was right to export?

3. What were the first steps you took in exporting?

- PROMPT IF NECESSARY:

* To which country did you first export and why?

\section{Section 2: Getting Started}

Now I would like to learn more about what happened during the early days of your exporting activity.

4. What was the major challenge you faced personally or that your business faced when you began to export? How did you deal with that challenge?

- THEN REPEAT AS OFTEN AS NECESSARY:

* Was there another major challenge you faced and how did you deal with it?

5. During the early stages of developing your export markets, did you make use of any public or private sector programs to help you get started at exporting.

- PROMPT IF NECESSARY:

* Was this program helpful? OR Were any of these programs helpful?

* Can you offer suggestions for improvement? 


\section{Section 3: Current Issues}

I would now like to ask you three questions pertaining to your current export activity

6. Now that you are exporting, what is the major challenge that you face personally or that your business faces that relates to exporting?

7. How are you dealing with this challenge?

- REPEAT AS NECESSARY

* Is there another challenge you would like to mention and how are you dealing with it?

8. Do you think there is a gender-specific aspect to any of the challenges you have mentioned at any point in this discussion?

9. When you completed your survey, you stated that you had used the following programs <LIST FROM SURVEY>. Can you tell us about your experiences, good and bad, with these programs and suggest how they might be improved?

10. Are there other programs or initiatives you currently use?

- PROMPT IF NECESSARY:

* Are these useful?

* Why do you say that?

\section{Section 4: Strategy}

We are almost finished. I have only two more questions.

11. Is there a strategy that you found particularly useful in gaining access to markets outside Canada?

12. Is there anything you think you have done differently because you are a woman.

13. If you could give one piece of advice to another business owner who was considering exporting, what would you say?

- PROMPT IF NECESSARY:

* Why do you say that?

END OF INTERVIEW

Note - To guide the development of the survey, the research team led exploratory focus group sessions involving approximately 45 participants in the "Trade '98" conference held in Magog, Quebec. The survey was then designed, with input from the Trade Research Coalition 